\title{
Understanding Cross-Country Differences in Exporter Premia: Comparable Evidence for 14 Countries
}

\section{International Study Group on Exports and Productivity (ISGEP)}

\begin{abstract}
We use comparable micro level panel data for 14 countries and a set of identically specified empirical models to investigate the relationship between exports and productivity. Our overall results are in line with the big picture that is by now familiar from the literature: exporters are more productive than nonexporters when observed and unobserved heterogeneity is controlled for, and these exporter productivity premia tend to increase with the share of exports in total sales; there is evidence in favour of self-selection of more productive firms into export markets, but nearly no evidence in favour of the learning-by-exporting hypothesis. We document that the exporter premia differ considerably across countries in identically specified empirical models. In a meta-analysis of our results we find, consistent with theoretical predictions, that productivity premia are larger in countries with lower export participation rates, with more restrictive trade policies, lower per capita GDP, less effective government and worse regulatory quality, and in countries exporting to relatively more distant markets. JEL no. F14, D21 Keywords: Exports; productivity; micro data; international comparison
\end{abstract}

Remark: The International Study Group on Exports and Productivity (ISGEP) consists of teams working with firm (establishment or enterprise) level data from 14 countries. Substantial contributions to the results reported in this paper were made by the following members of the teams: Austria (Leonhard Pertl, Stefano Schiavo), Belgium (Mirabelle Muuls, Mauro Pisu), Chile (Roberto Álvarez, Patricio Jaramillo, Ricardo A. López), China (Johannes Van Biesebroeck, Loren Brandt, Yifan Zhang), Colombia (Ana M. Fernandes, Alberto Isgut), Denmark (Rasmus Jørgensen, Ulrich Kaiser), France (Flora Bellone, Liza Jabbour, Patrick Musso, Lionel Nesta), Germany (Helmut Fryges, Joachim Wagner), Italy (Davide Castellani, Francesco Serti, Chiara Tomasi, Antonello Zanfei), Republic of Ireland (Stefanie A. Haller, Frances Ruane-The Irish contribution to this project is funded under a grant from the Irish Research Council for the Humanities and Social Sciences), Slovenia (Joze P. Damijan, Crt Kostevc, Saso Polanec), Spain (Jose C. Fariñas, Liza Jabbour, Juan A. Máñez, Ana Martin, Maria E. Rochina, Juan A. Sanchis), Sweden (Martin Andersson, Sara Johansson), and the United Kingdom (David Greenaway, Richard Kneller, Mauro Pisu). Ana Fernandes, Holger Görg and Alberto Isgut contributed to the metaanalysis. Joachim Wagner co-ordinates the group and serves as the corresponding author for this international comparison paper. For an earlier version reporting a large number of more detailed empirical results see ISGEP (2007). Please address correspondence to Joachim Wagner, Leuphana University of Lueneburg, Institute of Economics, Campus 4.210, D-21332 Lüneburg, Germany; e-mail: wagner@uni-lueneburg.de 


\section{Motivation}

In 1995 Bernard and Jensen published the first of a series of papers that use large comprehensive longitudinal data from surveys performed regularly by official statistics in the United States to look at differences between exporters and non-exporters in various dimensions of firm performance, including productivity (see Bernard and Jensen 1995, 1999, 2004a). These papers started a new strand of economic literature, as researchers all over the world began to use the rich data sets collected by the statistical offices to study the export activity of firms, its causes, and its consequences. The extent and causes of productivity differentials between exporters and their counterparts which sell on the domestic market only is one of the core topics addressed.

In this literature two alternative but not mutually exclusive hypotheses about why exporters can be expected to be more productive than nonexporting firms are discussed and investigated empirically (see Bernard and Jensen 1999; Bernard and Wagner 1997): The first hypothesis points to self-selection of the more productive firms into export markets. The reason for this is that there exist additional costs of selling goods in foreign countries. The range of extra costs include transportation costs, distribution or marketing costs, personnel with skills to manage foreign networks, or production costs in modifying current domestic products for foreign consumption. These costs provide an entry barrier that less productive firms cannot overcome. Furthermore, the behaviour of firms might be forwardlooking in the sense that the desire to export tomorrow may lead a firm to improve performance today to be competitive in the foreign market. Crosssection differences between exporters and non-exporters may therefore be partly explained by ex ante differences between firms: The more productive firms become exporters. The second hypothesis points to the role of postentry effects of exports on productivity. Knowledge flows from international buyers and competitors help to improve the post-entry performance of export starters. Furthermore, firms participating in international markets are exposed to more intense competition and must improve faster than firms who sell their products domestically only. Thus, exporting can make firms more productive.

Summarizing the results from a comprehensive survey of the empirical literature that covers 45 studies with data from 33 countries published between 1995 and 2006 Wagner (2007) argues that, details aside, the big picture that emerges after some ten years of micro-econometric research 
on the relationship between exporting and productivity is that exporters are more productive than non-exporters, and that the more productive firms self-select into export markets, while exporting does not necessarily improve productivity. ${ }^{1}$ However, this big picture hides a lot of heterogeneity. Cross-country comparisons, and even cross-study comparisons for the same country, are difficult because the studies differ in the details of the approach used. Therefore, the jury is still out on many of the issues regarding the relationship between exporting and productivity, including the absolute size of the productivity advantage needed to clear the export market hurdle and the reasons for differences in this size between countries, the reasons for the existence or the absence of ex post effects in some countries, the determinants of ex ante productivity premia of export starters, and the mechanisms by which learning from exporting occurs.

This paper contributes to filling this gap, by performing an international comparison, using a common methodology on similar data sets to assess the association between firms' productivity and exporting. Bringing together researchers with access to firm (or establishment) level data from 14 different countries (11 EU countries, plus Chile, Colombia from Latin America and China from Asia) we were able to define a common empirical methodology and each team could run the same routine on their data set. This allowed to perform a rather robust estimation (e.g. controlling for individual fixed effects or, alternatively, sector (4-digit) and time dummies, as well as firm/plant size and human capital) and achieve a rather high degree of comparability of results across a large number of countries. In our view, this makes this analysis a rather unique piece of work, which nicely complements other recent comparative studies on export and productivity. On the one hand, we apply a methodology very similar to Hallward-Driemeier et al. (2002), who compare productivity premia across five East Asian countries, but our analysis spans a larger number of countries, none of which was included in Hallward-Driemeier et al. (2002). On the other hand, our work is complementary to a recent Bruegel report on firm heterogeneity and international activities in Europe (Mayer and Ottaviano (2007), henceforth $\mathrm{MO}$ ). In fact, similarly to MO, our paper focuses mainly, although not exclusively, on EU countries. However, while MO address several issues, such as the concentration of exporting activities, export and FDI's premia, as well as intensive and extensive margins, our paper primarily focuses

${ }^{1}$ For contemporaneous but less comprehensive surveys of this literature with a somewhat different focus see López (2005) and Greenaway and Kneller (2007). 
on the export and productivity link. The narrower focus allows us to use more robust estimation methods and achieve greater international comparability. ${ }^{2}$ The main result of our analysis is that exporters are indeed more productive than non-exporting firms, and this appears to be mainly due to self-selection of more productive firms into exporting, while we find robust evidence for ex post effects of exports on productivity only for one out of 14 countries. These results are in line with those reported for the United States by Bernard and Jensen (2004b) and Bernard et al. (2007), henceforth BJRS, and many other country studies reviewed in Wagner (2007). However, we find that the export premium varies a lot across countries. Exploiting the large number of countries and the high degree of comparability of our results, we are in a position to perform a meta-analysis to explain that variation in cross-country productivity premia of exporters. Building on gravity models of international trade, as well as on recent theories of trade with heterogeneous firms, we provide a framework to select a set of country characteristics which help explain the cross-country variation in exporter premia. Consistent with theoretical predictions, we find that productivity premia are larger in countries with lower export participation rates, with more restrictive trade policies, lower per capita GDP, less effective government and worse regulatory quality, and in countries exporting to relatively more distant markets.

The rest of the paper is organised as follows: Section 2 provides information on the countries included, the data used, and descriptive statistics on some export characteristics. Section 3 reports the so-called exporter productivity premia, defined as the ceteris paribus percentage difference of productivity (measured as sales per worker) between exporters and nonexporters. Section 4 investigates ex ante and ex post productivity differences between exporters and non-exporters. Section 5 reports some robustness checks, including the estimation of exporter premia using, for a lower number of countries, different measures of productivity (such as value added per worker and total factor productivity (TFP)), and samples comprising also smaller firms (10-19 employees). Section 6 performs a meta-analysis aimed at exploring the factors behind country differences in exporters' premia. Section 7 concludes.

2 For example, MO address the productivity premia of exporters only for French firms, and report only unconditional differences in productivity, without controlling for individual fixed effects, nor sector and size effects. 


\section{Countries, Data Sets, and Descriptive Evidence on Exporter Characteristics}

A list of the 14 countries involved in this international comparison study, and some information on the data sets used, is given in Table 1. While most of the countries come from the European Union, Chile and Colombia from South America and China from Asia are included, too. ${ }^{3}$

Table 1: Countries Included in the International Comparison and Data Sets Used

\begin{tabular}{|c|c|c|}
\hline & Coverage & Years \\
\hline Austria & Manufacturing firms with at least 20 employees & 1999-2005 \\
\hline Belgium & All firms & 1996-2005 \\
\hline Chile & All establishments with at least 10 workers & $1990-1999$ \\
\hline China & $\begin{array}{l}\text { All state firms and all non-state firms with sales } \\
\text { above RMB } 5 \text { million }\end{array}$ & 1998-2005 \\
\hline Colombia & All establishments with at least 10 workers & $1981-1991$ \\
\hline Denmark & Universe offirms with minimum economic activity & 1999-2002 \\
\hline France & All firms with at least 20 active persons & 1990-2004 \\
\hline Germany & $\begin{array}{l}\text { All establishments with at least } 20 \text { active persons } \\
\text { (including owners) plus smaller establishments that } \\
\text { are part of a multi-establishment enterprise with } \\
\text { at least } 20 \text { active persons }\end{array}$ & 1995-2004 \\
\hline Italy & Universe of firms with 20 or more workers & 1989-1997 \\
\hline $\begin{array}{l}\text { Republic of } \\
\text { Ireland }\end{array}$ & $\begin{array}{l}\text { Census of industrial production. It includes all establish- } \\
\text { ments with with } 3 \text { or more employees in NACE Rev } 1.1 \\
\text { manufacturing sectors } 10-41 \text {. Establishments are not } \\
\text { necessarily dropped if they fall below } 3 \text { employees }\end{array}$ & 1991-2004 \\
\hline Slovenia & $\begin{array}{l}\text { All establishments, including firms with less than } \\
10 \text { employees }\end{array}$ & 1994-2002 \\
\hline Spain & $\begin{array}{l}\text { All firms with more than } 200 \text { employees plus a sample } \\
\text { of firms employing between } 10 \text { and } 200 \text { employees } \\
\text { selected according to a stratified random sampling } \\
\text { procedure }\end{array}$ & 1990-1999 \\
\hline Sweden & All firms & 1997-2004 \\
\hline $\begin{array}{l}\text { United } \\
\text { Kingdom }\end{array}$ & $\begin{array}{l}\text { All firms operating in the United Kingdom; over } \\
\text { representation of large firms because of missing } \\
\text { value problems }\end{array}$ & 1995-2004 \\
\hline
\end{tabular}

3 The composition of the sample of countries included is the result of a call for participation sent out by Joachim Wagner early in 2005 to all authors of studies covered in Wagner (2007). Unfortunately, not all of them agreed to participate, but, fortunately, others 
The data are either at the level of the establishment (the plant, the local production unit) or at the level of the firm (the legal unit). Unfortunately, it was neither possible to aggregate all establishment level data to the firm level, nor was it possible to split up firm level information to the establishment level. This different level of aggregation is one dimension on which the results reported in this study are not fully comparable across all countries. The other dimension is due to the different years covered. If we had limited the data used to years that are covered in all data sets, we would have only a small set of countries and a small number of years. Therefore, we decided to use all the information at hand, and to control for the different years covered in the estimation of the empirical models. Note that our analysis does control for both time periods and the unit of analysis when estimating specific relationships between exporter characteristics and firm/country variables.

Some of the data sets cover units with at least 20 employees, some with at least 10 employees, and some have information on all units. Results reported in this paper are for units with at least 20 employees; for those countries whose data sets cover units with at least 10 employees, comparable results are reported as robustness checks in Section 5. Furthermore, all computations are limited to units from manufacturing industries with NACE 2 letters code DA to DN (or ISIC code 15 to 36 ).

The exporter participation rate (defined as the percentage of exporting firms), the export intensity (defined as the average share of exports in total sales for exporting firms) and the contribution of different groups of exporters to aggregate exports in the 14 countries, ${ }^{4}$ are reported for the last year covered in each country's data set in Table 2.

Table 2 documents that both the exporter participation rate and the export intensity differ widely across the countries covered in this study. According to the information reported the average share of firms with at least 20 employees that export is 64 per cent. ${ }^{5}$ Across countries the participation rate ranges from 26.6 per cent for Colombia to 83 per cent for Sweden. Furthermore, the share of firms with at least 20 employees

joined later when they heard of the project. Researchers from countries not yet represented in the group are cordially invited to join-please contact Joachim Wagner by mailing to wagner@uni-lueneburg.de.

4 Given that there are still large differences between West Germany and the former communist East Germany, results are reported for both parts of Germany individually.

5 From now on we will use the term 'firm' to refer to the unit of analysis irrespective of whether the data are collected at the establishment or the enterprise level. 
Table 2: Exporter Participation Rate, Export Intensity and Share of Exports for Top Exporters

\begin{tabular}{lcccccc}
\hline & Year & $\begin{array}{c}\text { Participation } \\
\text { rate }\end{array}$ & $\begin{array}{c}\text { Export } \\
\text { intensity }\end{array}$ & & \multicolumn{3}{c}{ Share of exports } \\
\cline { 5 - 7 } & & & & per cent & $\begin{array}{c}\text { Top 5 } \\
\text { per cent }\end{array}$ & $\begin{array}{c}\text { Top 10 } \\
\text { per cent }\end{array}$ \\
\hline Austria & 2005 & 71.4 & 44.1 & 30.9 & 63.0 & 75.3 \\
Belgiun & 2005 & 80.3 & 44.3 & 43.3 & 69.9 & 78.9 \\
Chile & 1999 & 30.9 & 27.4 & 24.8 & 54.7 & 70.7 \\
China & 2005 & 30.4 & 60.3 & 42.6 & 63.2 & 70.7 \\
Colombia & 1991 & 26.6 & 17.8 & 27.9 & 66.2 & 79.2 \\
Denmark & 2002 & 77.2 & 30.5 & - & - & - \\
France & 2004 & 74.8 & 23.8 & 48.0 & 84.0 & 98.0 \\
West Germany & 2004 & 69.3 & 29.6 & 51.6 & 72.7 & 82.4 \\
East Germany & 2004 & 50.9 & 24.3 & 44.4 & 69.5 & 80.7 \\
Italy & 1997 & 69.3 & 33.1 & 43.6 & 67.7 & 77.2 \\
Rep. of Ireland & 2004 & 69.5 & 53.1 & 78.0 & 94.0 & 98.0 \\
Slovenia & 2002 & 81.3 & 54.7 & 43.4 & 75.7 & 85.6 \\
Spain & 1999 & 74.7 & 30.8 & 49.9 & 70.9 & 79.2 \\
Sweden & 2004 & 83.0 & 44.0 & 53.7 & 75.3 & 84.2 \\
United Kingdom & 2004 & 69.5 & 32.1 & 53.3 & 73.8 & 81.4 \\
\hline
\end{tabular}

Source: Own calculations.

that export within each industry ranges rather widely: the average rate is 79.74 per cent for Manufacture of chemicals, chemical products and man-made fibres, while the average is 46.6 per cent for Manufacture of food products, beverages and tobacco. For those countries whose data sets cover units with at least 10 employees, the average export participation is 54 per cent, with individual rates ranging from 18.2 per cent for Colombia to 74.6 per cent for Belgium. This reduction of 10 percentage points suggests that the probability of being an exporter is negatively associated with the size of the firm (ISGEP 2007).

Comparing the previous figures with two recent papers that offer evidence on exporter participation, our rates are roughly in line with those reported by MO (2007) for a group of European countries. However, the second paper by BJRS (2007) reports an 18 per cent participation rate for U.S. manufacturing firms in the year 2002. BJRS (2007) interprets the rather small participation rate of U.S. manufacturing firms as evidence that exporting is a rare firm activity. This discrepancy might be related to the fact that BJRS (2007) uses data from the Census of Manufacturers, which is an 
exhaustive data set, while our study and MO (2007) use surveys of units with at least 10 or 20 employees. As the probability of being an exporter is strongly and positively affected by the size of the firm, the use of restricted and/or exhaustive samples might explain the observed differences. Furthermore, the size of the domestic market in a country is a factor that influences the participation rate, i.e. the higher the size, the lower is the participation rate. This characteristic might be an additional factor explaining the lower participation rate in the United States compared to our participation rates and those in $\mathrm{MO}$ (2007).

Export intensity is measured as the share of exports in total sales per firm conditional on exporting. According to the values reported in Table 2, the average export intensity across countries is 37 per cent with individual intensities ranging from 17.8 per cent for Colombia to 60.3 per cent for China. BJRS (2007) reports an U.S. average export intensity of 14 per cent across all firms that export. The paper of MO (2007) does not report information on this characteristic of exporters.

A third characteristic reported in Table 2 refers to the contributions to aggregate exports of exporters occupying the top positions (1,5 and 10 per cent) in the ranking of exporting firms. Evidence reported by BJRS (2007) and MO (2007) suggest that aggregate exports are driven by a reduced number of top exporters. In particular, MO (2007) show, for a group of European countries, that the top 1 per cent, 5 per cent and 10 per cent of top exporters account for no less than 40 per cent, 70 per cent and 80 per cent of aggregate exports respectively. Estimates reported in Table 2 confirm this strong concentration of international trade across firms for the group of 14 countries.

Next, we identify some stylized facts about export participation and export intensity using a simple regression analysis. The objective is to explore the relationship between export activity at the firm level and some basic firm and country characteristics. In particular, the size of the firm and two country characteristics, the size of the domestic market and the level of per capita income, as a proxy for the degree of development, are the main characteristics we focus on. To be more specific, we estimate an equation of the form:

$$
\ln \left(\frac{p_{j}}{1-p_{j}}\right)=\beta X_{j}+\varepsilon_{j},
$$

where the dependent variable is the export participation (or export intensity) of country $j$, defined over four size groups of firms (20-49; 50-249; 
250-499 and 500+ employees) in the initial and the final year of the sample period for each country. The logit transformation of the dependent variable is introduced to deal with the fact that the dependent variables are proportions with values between 0 and $1 . X_{j}$ is a vector of control variables relating to firm size classes and country characteristics. Two additional controls are included, the first is a dummy set equal to one for the end-of-sample observations of each country, in order to check whether export participation (export intensity) varies over time. The second is a dummy variable that is equal to one if the observation belongs to a survey carried out at the establishment level. Results are provided in the first column of Panels A and $\mathrm{B}$ of Table 3.

Concerning size effects, both export participation and export intensity are positively associated with the size of the firm. However, in the relationship between export intensity and size there is a flat area, as the coefficients for the dummy variables for firms with 50-249 and 250-499 do not differ statistically. These results indicate that the probability of participating in export markets for a firm is greater the larger is its size. Furthermore, export intensity generally increases with firm size.

Concerning the two country characteristics, both the size and the degree of economic development have a significant impact on a firm's export activity. The size of the domestic market, proxied by the country's GDP, significantly reduces the share of firms participating in export markets. Simultaneously, the level of development, proxied by the GDP per capita, has a positive impact on the participation in export markets. Both variables, the level of GDP and GDP per capita, have a similar impact on export intensity: the size of the domestic market reduces the export intensity and the degree of development increases the export intensity. In the estimates of the second column the introduction of a dummy for China is required for the coefficients attached to GDP and GDP per capita to be statistically significant. $^{6}$

As regards the use of establishment surveys in a given country, this tends to overestimate export participation relative to other countries using firm surveys. The opposite is true with respect to export intensity. No systematic pattern is observed with respect to the evolution of export participation and export intensity over the period.

Finally, to check the robustness of our results we enlarge the set of characteristics by including some additional country variables used in the

${ }^{6}$ China is an outlier with the highest level of export intensity across exporting firms. 
Table 3: Export Participation, Export Intensity, Firm Size and Country Characteristics

Panel A: Export Participation, Country Characteristics and Firm Size

\begin{tabular}{|c|c|c|c|c|c|}
\hline & (1) & (2) & (3) & (4) & $(5)$ \\
\hline Dummy size $=50-249$ & $\begin{array}{c}1.072^{* * *} \\
(0.166)\end{array}$ & $\begin{array}{c}1.072^{* * *} \\
(0.166)\end{array}$ & $\begin{array}{c}1.072^{* * * *} \\
(0.132)\end{array}$ & $\begin{array}{c}1.072^{* * *} \\
(0.167)\end{array}$ & $\begin{array}{c}1.072^{* * *} \\
(0.166)\end{array}$ \\
\hline Dummy size $=250-499$ & $\begin{array}{c}1.971^{* * *} \\
(0.188)\end{array}$ & $\begin{array}{c}1.971^{* * *} \\
(0.188)\end{array}$ & $\begin{array}{c}1.971^{* * *} \\
(0.156)\end{array}$ & $\begin{array}{c}1.971^{* * *} \\
(0.188)\end{array}$ & $\begin{array}{c}1.971^{* * *} \\
(0.188)\end{array}$ \\
\hline Dummy size $=500+$ & $\begin{array}{c}2.373^{* * *} \\
(0.212)\end{array}$ & $\begin{array}{c}2.373^{* * *} \\
(0.213)\end{array}$ & $\begin{array}{c}2.373^{* * *} \\
(0.187)\end{array}$ & $\begin{array}{c}2.373^{* * *} \\
(0.213)\end{array}$ & $\begin{array}{c}2.373^{* * *} \\
(0.211)\end{array}$ \\
\hline GDP & $\begin{array}{c}-3.4 \mathrm{e}-04^{* * * *} \\
(6.2 \mathrm{e}-05)\end{array}$ & $\begin{array}{c}-3.5 \mathrm{e}-04^{* * *} \\
(6.2 \mathrm{e}-05)\end{array}$ & $\begin{array}{c}-2.7 \mathrm{e}-04^{* * *} \\
(5.1 \mathrm{e}-05)\end{array}$ & $\begin{array}{c}-3.5 \mathrm{e}-04^{* * *} \\
(7.0 \mathrm{e}-05)\end{array}$ & $\begin{array}{c}-3.3 \mathrm{e}-04^{* * *} \\
(6.3 \mathrm{e}-05)\end{array}$ \\
\hline GDP per capita & $\begin{array}{c}6.9 \mathrm{e}-05^{* * *} \\
(7.2 \mathrm{e}-06)\end{array}$ & $\begin{array}{c}5.4 \mathrm{e}-05^{* * *} \\
(1.6 \mathrm{e}-05)\end{array}$ & $\begin{array}{l}3.1-05^{* * *} \\
(9.1 \mathrm{e}-06)\end{array}$ & $\begin{array}{c}7.2 \mathrm{e}-05^{* * *} \\
(9.1 \mathrm{e}-06)\end{array}$ & $\begin{array}{c}5.7 \mathrm{e}-05^{* * *} \\
(1.1 \mathrm{e}-05)\end{array}$ \\
\hline Average tariff & - & $\begin{array}{l}-0.030 \\
(0.034)\end{array}$ & - & - & - \\
\hline Log of distance to exporting partners & - & - & $\begin{array}{c}-0.953^{* * *} \\
(0.156)\end{array}$ & - & - \\
\hline Regulatory quality & - & - & - & $\begin{array}{l}-0.070 \\
(0.172)\end{array}$ & - \\
\hline Government effectiveness & - & - & - & - & $\begin{array}{c}0.238 \\
(0.168)\end{array}$ \\
\hline Dummy end of period & $\begin{array}{l}-0.081 \\
(0.135)\end{array}$ & $\begin{array}{l}-0.014 \\
(0.161)\end{array}$ & $\begin{array}{c}0.082 \\
(0.118)\end{array}$ & $\begin{array}{l}-0.095 \\
(0.145)\end{array}$ & $\begin{array}{l}-0.030 \\
(0.144)\end{array}$ \\
\hline Dummy establishment level data & $\begin{array}{l}0.303^{* *} \\
(0.147)\end{array}$ & $\begin{array}{c}0.276^{* *} \\
(0.139)\end{array}$ & $\begin{array}{l}0.311^{* *} \\
(0.124)\end{array}$ & $\begin{array}{l}0.286^{*} \\
(0.167)\end{array}$ & $\begin{array}{c}0.286^{* *} \\
(0.144)\end{array}$ \\
\hline Constant & $\begin{array}{c}-1.445^{* * *} \\
(0.285)\end{array}$ & $\begin{array}{l}-0.916 \\
(0.558)\end{array}$ & $\begin{array}{c}6.829^{* * *} \\
(1.383)\end{array}$ & $\begin{array}{c}-1.416^{* * *} \\
(0.325)\end{array}$ & $\begin{array}{c}-1.515^{* * *} \\
(0.292)\end{array}$ \\
\hline Number of observations & 120 & 120 & 120 & 120 & 120 \\
\hline R-squared & 0.76 & 0.76 & 0.83 & 0.76 & 0.76 \\
\hline
\end{tabular}

Panel B: Export Intensity, Country Characteristics and Firm Size

\begin{tabular}{|c|c|c|c|c|c|}
\hline & (1) & $(2)$ & (3) & (4) & $(5)$ \\
\hline Dummy size $=50-249$ & $\begin{array}{l}0.288^{* *} \\
(0.129)\end{array}$ & $\begin{array}{l}0.288^{* *} \\
(0.129)\end{array}$ & $\begin{array}{l}0.288^{* *} \\
(0.126)\end{array}$ & $\begin{array}{l}0.288^{* *} \\
(0.129)\end{array}$ & $\begin{array}{l}0.288^{* *} \\
(0.130)\end{array}$ \\
\hline Dummy size $=250-499$ & $\begin{array}{l}0.380^{* *} \\
(0.185)\end{array}$ & $\begin{array}{c}0.380^{* *} \\
(0.186)\end{array}$ & $\begin{array}{l}0.380^{* *} \\
(0.173)\end{array}$ & $\begin{array}{l}0.380^{* *} \\
(0.187)\end{array}$ & $\begin{array}{l}0.380^{* *} \\
(0.186)\end{array}$ \\
\hline Dummy size $=500+$ & $\begin{array}{c}0.629^{* * *} \\
(0.155)\end{array}$ & $\begin{array}{c}0.629^{* * *} \\
(0.152)\end{array}$ & $\begin{array}{c}0.629^{* * *} \\
(0.152)\end{array}$ & $\begin{array}{c}0.629^{* * *} \\
(0.153)\end{array}$ & $\begin{array}{c}0.629^{* * * *} \\
(0.155)\end{array}$ \\
\hline GDP & $\begin{array}{c}-4 \mathrm{e}-04^{* * *} \\
(6.7 \mathrm{e}-05)\end{array}$ & $\begin{array}{c}-4.5 \mathrm{e}-04^{* * *} \\
(8.3 \mathrm{e}-05)\end{array}$ & $\begin{array}{c}-2.9 \mathrm{e}-04^{* * *} \\
(7.5 \mathrm{e}-05)\end{array}$ & $\begin{array}{c}-4.0 \mathrm{e}-04^{* * *} \\
(6.6 \mathrm{e}-05)\end{array}$ & $\begin{array}{c}-4.0 \mathrm{e}-04^{* * *} \\
(6.7 \mathrm{e}-05)\end{array}$ \\
\hline GDP per capita & $\begin{array}{c}5.6 \mathrm{e}-05^{* * *} \\
(1.0 \mathrm{e}-05)\end{array}$ & $\begin{array}{c}2.9 \mathrm{e}-05 \\
(2.2 \mathrm{e}-05)\end{array}$ & $\begin{array}{l}2.7 \mathrm{e}-05^{* *} \\
(1.1 \mathrm{e}-05)\end{array}$ & $\begin{array}{c}4.7 \mathrm{e}-05^{* * *} \\
(1.4 \mathrm{e}-05)\end{array}$ & $\begin{array}{c}5.2 \mathrm{e}-05^{* * *} \\
(1.4 \mathrm{e}-05)\end{array}$ \\
\hline Dummy China & $\begin{array}{c}3.766^{* * *} \\
(0.456)\end{array}$ & $\begin{array}{c}4.105^{* * *} \\
(0.530)\end{array}$ & $\begin{array}{c}3.208^{* * * *} \\
(0.467)\end{array}$ & $\begin{array}{c}3.972^{* * *} \\
(0.506)\end{array}$ & $\begin{array}{c}3.765^{* * *} \\
(0.456)\end{array}$ \\
\hline Average tariff & - & $\begin{array}{l}-0.064 \\
(0.047)\end{array}$ & - & - & - \\
\hline
\end{tabular}


Table 3: Continued

Panel B: Export Intensity, Country Characteristics and Firm Size

\begin{tabular}{|c|c|c|c|c|c|}
\hline & (1) & (2) & (3) & (4) & (5) \\
\hline Log of distance to exporting partners & - & - & $\begin{array}{c}-0.553^{* * *} \\
(0.167)\end{array}$ & - & - \\
\hline Regulatory quality & - & - & - & $\begin{array}{c}0.237 \\
(0.243)\end{array}$ & - \\
\hline Government effectiveness & - & - & - & - & $\begin{array}{c}0.074 \\
(0.202)\end{array}$ \\
\hline Dummy end of period & $\begin{array}{l}-0.071 \\
(0.131)\end{array}$ & $\begin{array}{c}0.059 \\
(0.179)\end{array}$ & $\begin{array}{c}0.047 \\
(0.111)\end{array}$ & $\begin{array}{l}-0.033 \\
(0.151)\end{array}$ & $\begin{array}{l}-0.055 \\
(0.149)\end{array}$ \\
\hline Dummy establishment level data & $\begin{array}{c}-0.619^{* * *} \\
(0.145)\end{array}$ & $\begin{array}{c}-0.736^{* * *} \\
(0.178)\end{array}$ & $\begin{array}{c}-0.514^{* * *} \\
(0.148)\end{array}$ & $\begin{array}{c}-0.598^{* * *} \\
(0.140)\end{array}$ & $\begin{array}{c}-0.624^{\text {*** }} \\
(0.148)\end{array}$ \\
\hline Constant & $\begin{array}{c}-1.568^{* * *} \\
(0.253)\end{array}$ & $\begin{array}{l}-0.488 \\
(0.843)\end{array}$ & $\begin{array}{c}3.302^{* *} \\
(1.383)\end{array}$ & $\begin{array}{c}-1.693^{* * *} \\
(0.278)\end{array}$ & $\begin{array}{c}-1.590^{* * *} \\
(0.258)\end{array}$ \\
\hline Number of observations & 120 & 120 & 120 & 120 & 120 \\
\hline R-squared & 0.45 & 0.47 & 0.51 & 0.46 & 0.45 \\
\hline
\end{tabular}

Note: Robust standard errors in parentheses. ${ }^{*},{ }^{* *},{ }^{* * *}$ denote significance at the 10,5 and 1 per cent level respectively.

Source: Own calculations.

meta-analysis of export premia in Section 6: an average tariff measure (to capture the trade policy stance in the country), a measure of the distance to a country's exporting partners (to proxy for transport costs faced by exporters), and the Kaufmann et al. (2007) indices on the effectiveness of the government and on regulatory quality (to proxy for the country institutional environment). ${ }^{7}$ We include one of these explanatory variables in each regression at a time because they turn out to be highly collinear. The results corresponding to these estimations are shown in columns (2) to (5) of Panels (A) and (B) of Table 3. The estimates of firm size, country size and level of development are quite robust to the introduction of this new set of variables as they remain unchanged both in sign and level of significance.

As for the results for the new variables, the negative and significant estimate of the distance to exporting partners variable in the export participation equation (column (3) of Panel (A)) suggests that higher transport costs increase the minimum productivity level required for exporting and thus reduces export participation. Like export participation, export inten-

7 The definition and method of construction of these variables can be found in the Appendix. 
sity is also negatively related to average distance to exporting partners (see column (3) of Panel (B)). More distant markets mean larger search costs for exporters and there exists a higher risk as there is more uncertainty about far away markets (Rauch and Watson 2003), which means that exporters would start in these markets with small export volumes. Further, neither the estimates corresponding to the two variables proxying for the country institutional environment nor that corresponding to the average tariff are statistically significant.

\section{Empirical Results I: Exporter Productivity Premia}

To investigate differences in productivity between exporters and nonexporters we start with the computation of the so-called exporter productivity premia, defined as the ceteris paribus percentage difference of productivity between exporters and non-exporters. Productivity is measured in a number of different ways in the literature, including labour productivity (defined as sales or value added per employee or per hour worked) and several variants of TFP. Given that information on value added, hours worked, and the capital stock used in the firm is available for only a few of the countries included in this international comparison project, we have to rely on the simplest measure of productivity, i.e. sales per employee (measured in constant prices). This decision has pros and cons. On the one hand, value added is not necessarily a better basis to measure productivity than sales, turnover or gross output. The reason is that value added does not track production in a year as closely as gross output or turnover would do (Oulton and O'Mahony 1994). Furthermore, Bartelsman and Doms (2000) point to the fact that heterogeneity in labour productivity has been found to be accompanied by similar heterogeneity in TFP; and Foster et al. (2005) show that productivity measures that are based on sales (i.e. quantities multiplied by prices) and measures that are based on quantities only are highly positively correlated. On the other hand, there is a concern about the association between the level of productivity (as measured by sales per employee) and different degrees of vertical integration at the firm level. Recent papers estimating exporter productivity as BJRS (2007) and MO (2007) use value added per worker and TFP as the preferred choice. We present results in this section using sales per employee as the measure of productivity and various robustness checks using value added per employee and TFP for some countries will be presented in Section 5 below. 
The exporter labour productivity premia are computed from a regression of log labour productivity on the current export status dummy and a set of control variables

$$
\ln L P_{i t}=a+\beta \text { Export }_{i t}+c \text { Control }_{i t}+e_{i t},
$$

where $i$ is the index of the firm, $t$ is the index of the year, $L P$ is labour productivity, Export is a dummy variable for current export status (1 if the firm exports in year $t, 0$ else), Control is a vector of control variables that includes the log of the number of employees and its squared value, the log of wages and salaries per employee (in constant prices), and a full set of interaction terms of 4-digit industry dummies ${ }^{8}$ and year dummies to control for industry-specific differences in characteristics and shocks, and $e$ is an error term. The exporter productivity premium, computed from the estimated coefficient $\beta$ as $100(\exp (\beta)-1)$, shows the average percentage difference in labour productivity between exporters and nonexporters controlling for the characteristics included in the vector Control. To account for unobserved plant heterogeneity due to time-invariant firm characteristics which might be correlated with the variables included in the empirical model and which might lead to a biased estimate of the exporter productivity premia, a variant of (2) is estimated including fixed firm effects, also.

To further motivate our control variables we mainly rely on the Melitz's (2003) model, which analyses intra-industry effects of international trade in productivity. As we are interested in analysing aggregated differences in the exporter premia across countries, we do not estimate our exporter premia separately by industry. To fit the Melitz's model we should, therefore, include in our aggregated specification as control variables a set of industry dummies to remove average productivity differences across industries. We could also argue that other control variables such as wages per employee and firm size might also be capturing on average important structural industry differences in wages and in firm size and that, therefore, we should also control for them. However, we have additional arguments for these two variables to be included in the control group. With respect to wages per employee, the productivity cut-off levels in the Melitz's (2003) model are determined under the assumption of symmetric countries (and one of the important dimensions of this symmetry is to keep wages equal across

8 3-digit industry dummies had to be used in the case of Italy and Spain. 
countries). ${ }^{9}$ Therefore, controlling for wages makes our exporter premia estimates closer to the symmetric countries assumption in the Melitz's model. As regards firm's size, a central point in his model is the existence of sunk fixed entry costs into exporting, one of the central elements to justify the existence of productivity cut-offs. According to the Melitz's model assumptions, such costs depend only on the export market and are common to all firms (which only differ in productivity). However, Máñez et al. (2008) obtain, using Spanish manufacturing data, that even after controlling for many things in estimation sunk costs in exporting are smaller for large firms. In such case, productivity cut-offs are firm's size dependent and to clean from this in the estimation of the exporter premia we should include firm's size as a control variable.

Now, let us further motivate the inclusion of time dummies and firm fixed effects as control variables when estimating the exporter premia. The Melitz's model only considers steady state equilibriums in which the aggregate variables remain constant over time and, therefore, assumes the absence of time shocks affecting firm's productivity. However, in real world there are shocks over time affecting firm's productivity. To get closer to the conditions in the theoretical Melitz's model we have to include time dummies as control variables. Furthermore, in the Melitz's model firm level heterogeneity means heterogeneity in firm level productivity, and not exactly the type of firm individual heterogeneity we try to control for by fixed effects estimation. Therefore, if firm fixed effects accounting for instance for managerial ability both increase firm productivity and the likelihood of exporting, estimating an exporter premia not controlling for them would not only capture the exporter premia but also the managerial ability premia.

Finally, a premium measure based on TFP will be probably closer to the Melitz's theoretical model, but given that we use labour productivity we need more control variables. For example, larger firms usually have larger capital stocks and if labour productivity is increasing on the capital stock it should also be increasing on firm size as a proxy. Similarly, if labour is heterogeneous and higher quality labour both receives higher wages and increases labour productivity, labour productivity should increase with average firm wages (a proxy for labour quality). The productivity measure in the Melitz's model is a theoretical measure that can hardly be found in real data because it is defined, among others, under the assumptions of

9 Wages differentials between countries can affect firms' productivity distributions, and this is something the Melitz's model tries to avoid. 
homogeneous labour and one production factor. Furthermore, productivity in Melitz (2003) is a random parameter to the firms, and does not depend on factors such as size and other firm characteristics. Thus, it is necessary to control for those observed and unobserved factors when estimating exporter premia based on labour productivity and real data.

Results for the estimated exporter productivity premia from empirical models with and without fixed firm effects for each of the 14 countries are reported in Table 4 for samples covering all firms with more than 20 employees. ${ }^{10}$

Looking at the results for all firms we find that the estimated premia are always statistically significantly different from zero, and often rather large, for pooled data. If fixed firm effects are added to control for unobserved heterogeneity the estimated premia are still statistically significant in all countries but Sweden, ${ }^{11}$ but the point estimates are much smaller compared to the results based on pooled data only. Thus, unobserved firm heterogeneity does matter.

The average exporter premium in the 14 countries, after controlling for individual fixed effects, is 7 per cent. The average premium without controlling for unobserved heterogeneity is 22.4 per cent. Therefore, the reduction in exporter premia after controlling for unobserved heterogeneity is substantial. BJRS (2007) report for U.S. manufacturing an exporter premium for value added per employee of 29.7 per cent, which reduces to 10.5 per cent after controlling for industry and size effects (no control for firm unobserved heterogeneity is considered). MO (2007) report only the premium for French exporters which is 31 per cent for value added per worker and without controls.

Taking as a reference the results from the model including fixed effects, Table 4 gives new insights on the relative magnitude of the export premia

10 To correct for the effects of extreme observations that are sometimes found in data from official statistics due to reporting errors or idiosyncratic events, the firms with the bottom/top 1 per cent labour productivity in a year are excluded from all computations for this and all following tables in this study.

11 There is no clear rationale for the insignificance of the productivity premia in the Swedish case. One plausible explanation is that Sweden has a limited domestic market and entry costs to the neighbouring countries (Denmark, Norway and Finland) are supposedly low (Andersson 2007). Another is that many Swedish firms belong to multinational corporations with established trading networks to foreign countries. Andersson et al. (2008) show that about 35 per cent of Swedish manufacturing firms belong to multinational enterprises (MNEs) and that MNEs are responsible for over 90 per cent of the total value of Sweden's exports. 
ISGEP: Understanding Cross-Country Differences in Exporter Premia

Table 4: Exporter Productivity Premia (percentage) I: Exporter Dummy

\begin{tabular}{|c|c|c|c|c|}
\hline & Years & $\begin{array}{c}\text { Pooled } \\
\beta \\
(p \text {-value })\end{array}$ & $\begin{array}{c}\text { Fixed effects } \\
\beta \\
(p \text {-value })\end{array}$ & $\begin{array}{l}\text { Number of } \\
\text { observations } \\
\quad(N \times T)\end{array}$ \\
\hline Austria & 1999-2005 & $\begin{array}{c}17.5 \\
(0.00)\end{array}$ & $\begin{array}{c}5.3 \\
(0.00)\end{array}$ & 26,404 \\
\hline Belgium & 1996-2005 & $\begin{array}{c}57.8 \\
(0.00)\end{array}$ & $\begin{array}{c}9.8 \\
(0.00)\end{array}$ & 29,035 \\
\hline Chile & 1990-1999 & $\begin{array}{c}21.7 \\
(0.00)\end{array}$ & $\begin{array}{c}7.3 \\
(0.00)\end{array}$ & 33,869 \\
\hline China & 1998-2005 & $\begin{array}{c}15.7 \\
(0.00)\end{array}$ & $\begin{array}{c}10.9 \\
(0.00)\end{array}$ & $1,310,771$ \\
\hline Colombia & 1981-1991 & $\begin{array}{c}26.9 \\
(0.00)\end{array}$ & $\begin{array}{c}16.4 \\
(0.00)\end{array}$ & 46,142 \\
\hline Denmark & 1999-2002 & $\begin{array}{c}38.5 \\
(0.00)\end{array}$ & $\begin{array}{c}6.6 \\
(0.00)\end{array}$ & 29,161 \\
\hline France & 1990-2004 & $\begin{array}{c}20.0 \\
(0.00)\end{array}$ & $\begin{array}{c}7.6 \\
(0.00)\end{array}$ & 297,393 \\
\hline West Germany & 1995-2004 & $\begin{array}{c}15.4 \\
(0.00)\end{array}$ & $\begin{array}{c}7.2 \\
(0.00)\end{array}$ & 311,625 \\
\hline East Germany & 1995-2004 & $\begin{array}{c}14.3 \\
(0.00)\end{array}$ & $\begin{array}{c}5.6 \\
(0.00)\end{array}$ & 61,140 \\
\hline Italy & 1989-1997 & $\begin{array}{c}40.3 \\
(0.00)\end{array}$ & $\begin{array}{c}3.6 \\
(0.00)\end{array}$ & 175,032 \\
\hline Rep. of Ireland & 1991-2004 & $\begin{array}{c}14.6 \\
(0.00)\end{array}$ & $\begin{array}{c}7.3 \\
(0.00)\end{array}$ & 27,232 \\
\hline Slovenia & 1994-2002 & $\begin{array}{c}9.6 \\
(0.00)\end{array}$ & $\begin{array}{c}5.0 \\
(0.00)\end{array}$ & 9,909 \\
\hline Spain & 1990-1999 & $\begin{array}{c}27.5 \\
(0.00)\end{array}$ & $\begin{array}{c}8.1 \\
(0.00)\end{array}$ & 12,806 \\
\hline Sweden & 1997-2004 & $\begin{array}{c}6.7 \\
(0.00)\end{array}$ & $\begin{array}{c}-0.1 \\
(0.85)\end{array}$ & 31,838 \\
\hline United Kingdom & 1995-2004 & $\begin{array}{c}9.9 \\
(0.00)\end{array}$ & $\begin{array}{c}3.9 \\
(0.00)\end{array}$ & 52,593 \\
\hline
\end{tabular}

Note: Results are for firms from ISIC industries 15-36 with at least 20 employees at the median over the years covered in the panel. The firms with the bottom/top 1 per cent of labour productivity (defined as total sales per employee) in a year are excluded from all computations. $\beta$ is the estimated regression coefficient from an OLS-regression of log (labour productivity) on a dummy variable for exporting firms, controlling for the log of the number of employees and its squared value, the log of wages and salaries per employee, and a full set of interaction terms of 4-digit industry dummies and year dummies; the fixed effects model adds firm fixed effects. To facilitate interpretation the estimated coefficients for the exporter dummy variable have been transformed by $100(\exp (\beta)-1)$. $p$ is the prob-value. $N \times T$ is the number of observations. 
across countries. For a large majority of countries ( 6 among the 13 for which export premia are found to be statistically significant), the premia lie in a range of 6.6 to 8.1 per cent. Two subgroups of countries emerge however which display relatively high or relatively low export premia. The first subgroup includes Colombia (16.4 per cent), China (10.9 per cent) and Belgium (9.8 per cent) while the second subgroup includes East Germany (5.6 per cent), Austria (5.3 per cent), Slovenia (5 per cent), the United Kingdom (3.9 per cent), and Italy (3.6 per cent).

To investigate how the premia vary with export intensity, a modified version of the empirical model (2) is used where the dummy variable indicating the export status is replaced by the share of exports in total sales and its squared value. The descriptive results of this regression are reported in Table 5.

Given that the results differ considerably when fixed firm effects are added to the model estimated with pooled data, we again focus on the results from the empirical model controlling for unobserved firm heterogeneity. From the results reported in Table 5 for all firms we conclude that the share of exports in total sales matters for the size of the exporter productivity premium in all countries but Slovenia ${ }^{12}$ because at least one of the two estimated coefficients (on the share of exports in total sales, or on its squared value) is statistically different from zero at the 5 per cent level. Looking at the pattern of the signs of the estimated coefficients, and focusing on the point estimates that are statistically different from zero at the 5 per cent level, we find that the exporter productivity premium varies with the share of exports in total sales as follows:

- it increases (either both estimated coefficients have a positive sign, or the coefficient with a negative sign is statistically insignificant) in Austria, West Germany, East Germany, Italy, Republic of Ireland, and the United Kingdom; ${ }^{13}$

- it increases at a decreasing rate (the coefficient of the share of exports in total sales is positive, the coefficient of the squared value is negative, and the estimated maximum is reached for a value of the share of exports that is either higher than 100 per cent, or very high compared to the average

\footnotetext{
12 This is in line with findings from other studies using Slovenian firm data; for a discussion see Damijan et al. (2004) and Damijan and Kostevc (2006).

13 In the United Kingdom data the sign pattern is " $-/+$ ", but the estimated minimum of the parabola is 8.3 per cent, this indicates that the exporter premium is increasing in the share of exports in total sales in general.
} 
Table 5: Exporter Productivity Premia II: Share of Exports in Total Sales ( $\beta$ 1) and Its Squared Value ( $\beta$ 2)

\begin{tabular}{|c|c|c|c|c|c|}
\hline & \multirow[t]{2}{*}{ Years } & \multicolumn{2}{|c|}{ Pooled } & \multicolumn{2}{|c|}{ Fixed effects } \\
\hline & & $\begin{array}{c}\beta 1 \\
(p \text {-value })\end{array}$ & $\begin{array}{c}\beta 2 \\
(p \text {-value })\end{array}$ & $\begin{array}{c}\beta 1 \\
(p \text {-value })\end{array}$ & $\begin{array}{c}\beta 2 \\
\text { (p-value) }\end{array}$ \\
\hline Austria & (1999-2005) & $\begin{array}{l}0.579 \\
(0.00)\end{array}$ & $\begin{array}{c}-0.295 \\
(0.00)\end{array}$ & $\begin{array}{l}0.229 \\
(0.00)\end{array}$ & $\begin{array}{l}0.117 \\
(0.06)\end{array}$ \\
\hline Belgium & $(1996-2005)$ & $\begin{array}{l}1.397 \\
(0.00)\end{array}$ & $\begin{array}{c}-1.000 \\
(0.00)\end{array}$ & $\begin{array}{l}0.576 \\
(0.00)\end{array}$ & $\begin{array}{c}-0.365 \\
(0.00)\end{array}$ \\
\hline Chile & (1990-1999) & $\begin{array}{l}0.882 \\
(0.00)\end{array}$ & $\begin{array}{c}-0.911 \\
(0.00)\end{array}$ & $\begin{array}{l}0.329 \\
(0.00)\end{array}$ & $\begin{array}{l}-0.223 \\
(0.001)\end{array}$ \\
\hline China & $(1998-2005)$ & $\begin{array}{c}0.912 \\
(0.00)\end{array}$ & $\begin{array}{c}-0.914 \\
(0.00)\end{array}$ & $\begin{array}{l}0.436 \\
(0.00)\end{array}$ & $\begin{array}{c}-0.432 \\
(0.00)\end{array}$ \\
\hline Colombia & $(1981-1991)$ & $\begin{array}{l}0.540 \\
(0.00)\end{array}$ & $\begin{array}{l}-0.122 \\
(0.002)\end{array}$ & $\begin{array}{l}0.620 \\
(0.00)\end{array}$ & $\begin{array}{c}-0.081 \\
(0.00)\end{array}$ \\
\hline Denmark & $(1999-2002)$ & $\begin{array}{c}0.97 \\
(0.00)\end{array}$ & $\begin{array}{l}-0.64 \\
(0.00)\end{array}$ & $\begin{array}{c}0.38 \\
(0.00)\end{array}$ & $\begin{array}{l}-0.35 \\
(0.00)\end{array}$ \\
\hline France & $(1990-2004)$ & $\begin{array}{l}0.734 \\
(0.00)\end{array}$ & $\begin{array}{c}-0.565 \\
(0.00)\end{array}$ & $\begin{array}{l}0.331 \\
(0.00)\end{array}$ & $\begin{array}{c}-0.120 \\
(0.00)\end{array}$ \\
\hline West Germany & $(1995-2004)$ & $\begin{array}{l}0.006 \\
(0.00)\end{array}$ & $\begin{array}{c}-0.00004 \\
(0.00)\end{array}$ & $\begin{array}{l}0.003 \\
(0.00)\end{array}$ & $\begin{array}{c}-0.000002 \\
(0.30)\end{array}$ \\
\hline East Germany & $(1995-2004)$ & $\begin{array}{l}0.007 \\
(0.00)\end{array}$ & $\begin{array}{c}-0.00006 \\
(0.00)\end{array}$ & $\begin{array}{l}0.0031 \\
(0.00)\end{array}$ & $\begin{array}{c}0.0000007 \\
(0.20)\end{array}$ \\
\hline Italy & (1989-1997) & $\begin{array}{l}0.927 \\
(0.00)\end{array}$ & $\begin{array}{c}-0.552 \\
(0.00)\end{array}$ & $\begin{array}{l}0.090 \\
(0.00)\end{array}$ & $\begin{array}{l}0.036 \\
(0.05)\end{array}$ \\
\hline Rep. of Ireland & $(1991-2004)$ & $\begin{array}{l}0.097 \\
(0.01)\end{array}$ & $\begin{array}{l}0.134 \\
(0.00)\end{array}$ & $\begin{array}{l}0.220 \\
(0.00)\end{array}$ & $\begin{array}{l}0.011 \\
(0.82)\end{array}$ \\
\hline Slovenia & $(1994-2002)$ & $\begin{array}{l}0.052 \\
(0.83)\end{array}$ & $\begin{array}{l}0.001 \\
(0.06)\end{array}$ & $\begin{array}{l}0.009 \\
(0.34)\end{array}$ & $\begin{array}{c}-0.00004 \\
(0.07)\end{array}$ \\
\hline Spain & (1990-1999) & $\begin{array}{l}0.430 \\
(0.00)\end{array}$ & $\begin{array}{l}-0.283 \\
(0.003)\end{array}$ & $\begin{array}{l}0.354 \\
(0.00)\end{array}$ & $\begin{array}{c}-0.179 \\
(0.00)\end{array}$ \\
\hline Sweden & $(1997-2004)$ & $\begin{array}{l}0.151 \\
(0.00)\end{array}$ & $\begin{array}{c}-0.016 \\
(0.00)\end{array}$ & $\begin{array}{l}-0.08 \\
(0.00)\end{array}$ & $\begin{array}{l}0.001 \\
(0.38)\end{array}$ \\
\hline \multicolumn{2}{|c|}{ United Kingdom (1995-2004) } & $\begin{array}{l}0.025 \\
(0.37)\end{array}$ & $\begin{array}{l}0.034 \\
(0.33)\end{array}$ & $\begin{array}{c}-0.015 \\
(0.71)\end{array}$ & $\begin{array}{l}0.090 \\
(0.05)\end{array}$ \\
\hline
\end{tabular}

Note: Results are for firms from ISIC industries 15-36 with at least 20 employees at the median over the years covered in the panel. The firms with the bottom/top 1 per cent of labour productivity (defined as total sales per employee) in a year are excluded from all computations. $\beta 1$ and $\beta 2$ are the estimated regression coefficients from an OLS-regression of $\log$ (labour productivity) on the share of exports in total sales and its squared value, respectively, controlling for the log of the number of employees and its squared value, the log of wages and salaries per employee, and a full set of interaction terms of 4-digit industry dummies and year dummies; the fixed effects model adds firm fixed effects. $p$ is the prob-value. 
share of exports in total sales of the exporting firms in Table 2 in Belgium, Chile, Colombia, Denmark, France, and Spain;

- it increases, reaches a maximum at around 50 per cent, and decreases afterwards in China; and

- it decreases (the positive coefficient of the squared term is statistically insignificant) in Sweden.

To sum up, we find empirical evidence that the exporter productivity premia tend to increase generally with the share of exports in total sales. From a theoretical point of view, we find three arguments explaining a positive relationship between export intensity and exporter premia. First, empirical evidence suggests that the most productive exporting firms sell to a higher number of export markets (Muûls and Pisu 2007). Should increasing the number of export destinations increase export intensity, more productive firms are more export intensive and, therefore, export intensity is positively correlated with exporter premia. Although Melitz (2003) restricts export costs to be equal across export destinations, he suggests the possibility of relaxing this assumption to explain why some firms export only to some countries. This would allow generating a positive relationship between firm's productivity and number of export destinations (for such extension see Melitz and Ottaviano (2008)). Further, this first argument is reinforced by the fact that more productive firms are able to sell not only to more markets but also to tougher markets, for which MO (2007) find evidence of a larger per firm average value of exports.

Second, in Melitz's (2003) model fixed costs of exporting do not vary with export volume. Thus, the higher these fixed export costs the higher the firms' incentives to increase export volume (and so, conditional on firms' size, export intensity) to spread these costs among more units (cost spreading argument). If we jointly consider that higher fixed costs of exporting increase the productivity cut-offs (and so the exporter premia), and that (conditional on firm size) cost spreading will allow more export intensive firms to face such costs, we could hypothesize the existence of a positive relationship between export intensity and exporter premia.

Third, there is an argument coming from the learning-by-exporting hypothesis instead of the self-selection of more productive firms into export markets. According to this, the degree of exposure to exporting markets, measured by export intensity as a proxy, matters to explain export premia whenever the learning process is linked to the degree of exposure. Firms can learn more from exporting if export volumes are large. 


\section{Empirical Results II: Ex Ante and Ex Post Exporter Productivity Premia}

The empirical results reported and discussed in Section 3 relate to the correlation between labour productivity and exports. Regarding the direction of causality between these two dimensions of firm performance, there are two not mutually exclusive hypotheses mentioned in the introduction. To shed light on the empirical validity of the first hypothesis-namely, that the more productive firms sell abroad-the pre-entry differences in labour productivity between export starters and non-exporters are investigated next. If good firms become exporters then we should expect to find significant differences in performance measures between future export starters and future non-starters several years before some of them begin to export. To test whether today's export starters were more productive than today's nonexporters several years back when all of them did not export, all firms that did not export between year $t-3$ and $t-1$ are selected, and the average difference in labour productivity in year $t-3$ between those firms who did export in year $t$ and those who did not is computed. More formally, we estimate the following empirical model for each cohort of export starters and non-starters:

$$
\ln L P_{i t-3}=a+\beta \text { Export }_{i t}+c \text { Control }_{i t-3}+e_{i t},
$$

where $i$ is the index of the firm, $t$ is the index of the year, $L P$ is labour productivity in year $t-3$, Export is a dummy variable for current export status ( 1 if the firm exports in year $t, 0$ else), Control is a vector of control variables that includes the log of the number of employees and its squared value, the log of wages and salaries per employee (in constant prices), and a set of 4-digit industry dummies ${ }^{14}$, and $e$ is an error term. The preentry premium, computed from the estimated coefficient $\beta$ as $100(\exp (\beta)$ -1 ), shows the average percentage difference between today's exporters and today's non-exporters three years before starting to export, controlling for the characteristics included in the vector Control.

Results are reported in Table 6. As can be seen from column (1), the number of export starters in the data sets used is often rather small. Therefore, it comes as no surprise that for some countries (Austria, Belgium, the Republic of Ireland, Slovenia, Sweden, and the United Kingdom) the point estimates for the ex ante labour productivity premia of export starters

14 3-digit industry dummies had to be used in the case of Italy and Spain. 
Table 6: Productivity Premia of Export Starters vs. Non-Starters Three Years before the Start: Summary of Results from Equation (3)

\begin{tabular}{|c|c|c|c|c|c|c|}
\hline & $\begin{array}{c}\text { Median } \\
\text { (no. of } \\
\text { starters } \\
\text { per } \\
\text { year) } \\
\text { (1) }\end{array}$ & $\begin{array}{l}\text { Median } \\
\text { (no. of } \\
\text { starters/ } \\
\text { total no. of } \\
\text { observations) } \\
\text { (per cent) } \\
\text { (2) }\end{array}$ & $\begin{array}{l}\text { No. of } \\
\text { regressions }\end{array}$ & $\begin{array}{l}\text { No. of } \beta \\
\text { coefficients } \\
\text { significant } \\
\text { at the } 5 \text { per } \\
\text { cent level } \\
\text { (4) }\end{array}$ & $\begin{array}{l}\text { No. of } \beta \\
\text { coefficients } \\
\text { significant } \\
\text { at the } 10 \text { per } \\
\text { cent level } \\
\text { (5) }\end{array}$ & $\begin{array}{c}\text { Pre-entry } \\
\text { productivity } \\
\text { premia } \\
\text { (median of } \\
\text { estimated } \beta \text { ) } \\
\text { (6) }\end{array}$ \\
\hline Austria & 39 & 5 & 4 & 1 & 1 & 0.08 \\
\hline Belgium & 32 & 11 & 7 & 1 & 1 & 6.07 \\
\hline Chile & 47 & 3 & 7 & 3 & 4 & 12.05 \\
\hline China & 2,254 & 4 & 5 & 5 & 5 & 20.83 \\
\hline Colombia & 107 & 4 & 8 & 4 & 4 & 15.85 \\
\hline France & 300 & 11 & 12 & 10 & 10 & 7.51 \\
\hline West Germany & 338 & 4 & 7 & 2 & 3 & 4.73 \\
\hline East Germany & 118 & 5 & 7 & 1 & 1 & 5.60 \\
\hline Italy & 255 & 11 & 6 & 6 & 6 & 17.44 \\
\hline Republic of Ireland & 23 & 7 & 11 & 0 & 1 & 16.08 \\
\hline Slovenia & 15 & 16 & 6 & 1 & 1 & -1.24 \\
\hline Spain & 26 & 13 & 7 & 0 & 4 & 24.07 \\
\hline Sweden & 41 & 1 & 5 & 0 & 0 & -1.24 \\
\hline United Kingdom & 33 & 4 & 7 & 1 & 1 & 10.91 \\
\hline Total & & & 99 & 35 & 42 & \\
\hline
\end{tabular}

Note: Results are for firms from ISIC industries 15-36 with at least 20 employees at the median over the years covered in the panel. The firms with the bottom/top 1 per cent of labour productivity (defined as total sales per employee) in a year are excluded from all computations. The labour productivity premia are estimated in an OLS-regression of $\log$ (productivity) on a dummy variable for export starters controlling for the log of number of employees and its squared value, log wages and salaries per employee, and dummy variables for 4-digit industries, all measured before the start. This table summarises the results. Column (6) reports the median of the estimated coefficients for each country (to facilitate interpretation the estimated coefficients for the exporter dummy variable have been transformed by $100(\exp (\beta)-1))$. Column (3) reports the number of regressions performed for each country which is equal to the number of cohorts of exporter starters with information available. Columns (4) and (5) report the number of coefficients significant at the 5 and 10 per cent level when the $\beta$ coefficient is, as expected, positive.

are nearly always statistically insignificant. However, when the estimated ex ante premia in these countries are statistically different from zero, they are positive. Ex ante productivity differences are usually in the expected direction but rather small. Further, for Chile, China and Colombia (the three less developed countries covered in our study) 65 per cent of the cohorts of starters have an ex ante productivity premia that is statistically significant at 10 per cent or lower. For the group that includes France, Italy, West Germany (three countries with a large cohort of export starters in their samples) and Spain, 72 per cent of the cohorts of starters in the four 
countries have ex ante productivity premia that are statistically significant at a level of ten per cent or lower. ${ }^{15}$ To summarise, we find evidence in favour of the self-selection hypothesis for the less developed countries in our sample and for EU-countries with suitable data sets including a large enough number of export starters to investigate this issue. Overall, in 42 cohorts out of a total number of 99 cohorts that have been compared, the pre-entry productivity premium is positive and statistically significant. If we restrict the comparison to the group of countries with cohorts of export starters including a large enough number of firms, the percentage of cases with a statistically significant difference rises up to a 69 per cent.

To test the second hypothesis mentioned in the introduction-namely, that exporting fosters productivity-the post-entry differences in productivity growth between export starters and non-exporters are investigated. This test is based on a comparison of firms that did not export in years $t-3$ to $t-1$, but exported in year $t$ and in at least two years between the years $t+1$ and $t+3$ - these are the export starters—-with firms from a control group that did not export in any year between $t-3$ and $t+3$. The empirical model used is

$$
\ln L P_{i t+3}-\ln L P_{i t+1}=a+\beta \text { Export }_{i t}+c \text { Control }_{i t}+e_{i t},
$$

where $i$ is the index of the firm, $t$ is the index of the year, $L P$ is labour productivity, Export is a dummy variable that equals 1 for export starters and that equals zero for the firms from the control group, Control is a vector of control variables defined above, and $e$ is an error term. The post-entry premium, computed from the estimated coefficient $\beta$ as $100(\exp (\beta)-1)$, shows the average percentage difference in the growth of labour productivity between the export starters and non-exporters over the three years after beginning to export, controlling for the characteristics included in the vector Control.

A summary of the results is reported in Table 7. Again, the number of export starters that can be monitored with the data sets available for this study are too small for most countries to offer a solid basis for the empirical comparison. Overall, the results are mixed, with positive and negative statistically significant estimates for some years in some countries.

15 Countries in both groups (less and more developed) for which the data sets allow doing the analysis by including firms with more than 10 employees instead of only with more than 20, the results about the ex ante export productivity premia are even reinforced, both in terms of the number of years where the effect is significant and the positive magnitute of the effect, that increases (ISGEP 2007). 
Table 7: Productivity Growth Differences between Export Starters and Non-Starters Three Years after the Start: Summary of Results from Equation (4)

\begin{tabular}{|c|c|c|c|c|c|c|}
\hline & $\begin{array}{c}\text { Median } \\
\text { (no. of } \\
\text { starters } \\
\text { per } \\
\text { year) } \\
\text { (1) }\end{array}$ & $\begin{array}{l}\text { Median } \\
\text { (no. of } \\
\text { starters/ } \\
\text { total no. of } \\
\text { observations) } \\
\text { (per cent) } \\
\text { (2) }\end{array}$ & $\begin{array}{l}\text { No. of } \\
\text { regressions }\end{array}$ & $\begin{array}{l}\text { No. of } \beta \\
\text { coefficients } \\
\text { significant } \\
\text { at the } 5 \text { per } \\
\text { cent level } \\
\text { (4) }\end{array}$ & $\begin{array}{l}\text { No. of } \beta \\
\text { coefficients } \\
\text { significant } \\
\text { at the } 10 \text { per } \\
\text { cent level } \\
\text { (5) }\end{array}$ & $\begin{array}{l}\text { Productivity } \\
\text { growth } \\
\text { premia } \\
\text { (median of } \\
\text { estimated } \beta \text { ) } \\
\text { (6) }\end{array}$ \\
\hline Austria & 16 & 3 & 1 & 0 & 0 & 0.06 \\
\hline Belgium & 11 & 7 & 4 & 1 & 2 & 19.26 \\
\hline Chile & 42 & 3 & 4 & 0 & 0 & 1.89 \\
\hline China & 538 & 2 & 2 & 0 & 0 & -4.51 \\
\hline Colombia & 36 & 2 & 5 & 0 & 0 & -0.06 \\
\hline France & 173 & 12 & 9 & 0 & 0 & -0.22 \\
\hline West Germany & 187 & 3 & 4 & 0 & 0 & -0.04 \\
\hline East Germany & 61 & 3 & 4 & 1 & 1 & -2.23 \\
\hline Italy & 144 & 11 & 3 & 2 & 3 & 4.32 \\
\hline Republic of Ireland & 18 & 8 & 8 & 1 & 1 & -1.35 \\
\hline Slovenia & 4 & 9 & 3 & 0 & 0 & 6.17 \\
\hline Spain & 16 & 11 & 4 & 0 & 0 & 5.19 \\
\hline Sweden & 52 & 2 & 2 & 0 & 0 & 2.13 \\
\hline United Kingdom & 19 & 5 & 4 & 1 & 1 & 3.9 \\
\hline Total & & & 56 & 6 & 8 & \\
\hline
\end{tabular}

Note: Results are for firms from ISIC industries 15-36 with at least 20 employees at the median over the years covered in the panel. The firms with the bottom/top 1 per cent of labour productivity (defined as total sales per employee) in a year are excluded from all computations. The labour productivity premia are estimated in an OLS-regression of the growth rate of labour productivity (computed as the difference of the log of labour productivity in $t+3$ and $t+1$ ) on a dummy variable for export starters controlling for the log of number of employees and its squared value, log wages and salaries per employee, and dummy variables for 4-digit industries, all measured at the start year $t$. This table summarises the results. Column (6) reports the median of the estimated coefficients for each country (to facilitate interpretation the estimated coefficients for the exporter dummy variable have been transformed by $100(\exp (\beta)-1))$. Column $(3)$ reports the number of regressions performed for each country which is equal to the number of cohorts of exporter starters with information available. Columns (4) and (5) report the number of coefficients significant at the 5 and 10 per cent level when the $\beta$ coefficient is, as expected, positive.

For the less developed countries in our sample (Chile, China and Colombia), for which we found evidence in favour of the self-selection hypothesis, we only get significant coefficients for China but with a negative premium for ex post export productivity growth. Looking at the results for France, West Germany and Italy, countries where the number of starters seems to be large enough for our purpose and for which we also found evidence in favour of the self-selection hypothesis, we find evidence in favour of the learning-byexporting hypothesis for Italy only. For the remaining countries we do not 
find a clear statistically significant pattern. Therefore, we can conclude from our study, and similarly to $\mathrm{MO}$ (2007) who did the analysis of the learningby-exporting hypothesis only for France, Norway and Germany, that "there is no clear evidence of firms performing differently after accessing foreign markets". Overall, only in 8 cohorts out of a total number of 56 cohorts (14 per cent) that have been compared, post-entry productivity growth indicates that entering exporters perform better than non-exporters. ${ }^{16}$

\section{Robustness Checks}

To check the robustness of our results we repeat our empirical analysis with different measures of productivity, and with samples of firms having at least 10 employees, for the countries where required data are available.

As a first robustness check, we repeat the calculations in Table 4 using two different dependent variables. Subtracting intermediate inputs (which include raw materials and energy where possible) from total sales, we construct value added and divide it by employment as before to obtain a more customary measure of labour productivity $(V A / L)$. Subtracting $\left(1-s_{j}\right)^{*} \ln (K / L)$ from value added per worker, where $s_{j}$ is the wage share in value added for industry $j$, we obtain an estimate of TFP which is our third dependent variable.

In Table 8 we report results for these two new dependent variables. For data availability reasons, the results can be obtained only for a subset of the countries. As the sample size is often reduced due to missing value added or capital information, we report results using all three dependent variables on the sub-sample for which we can measure TFP. As before, we drop the outliers at the top and bottom 1 per cent of the productivity distributions. The reported statistics are calculated exactly as before in Table 4 .

The results prove remarkably robust for the new dependent variables. The exporter productivity premia in Table 8 remain positive and significantly different from zero for all countries if we use value added per worker instead of sales per worker. The magnitudes of the effects are uniformly smaller, and the declines range from a factor of seven for Belgium to less than 10 per cent for Colombia. Using TFP as the dependent variable, some

\footnotetext{
16 Results do not perceptibly change for the countries where we could perform the analysis using firms with more than 10 employees. Applying our definition of export starter to these wider samples does only incorporate a few more export starters from the size class of 10 to 20 employees (ISGEP 2007).
} 
Table 8: Exporter Premia with Different Measures of Productivity

\begin{tabular}{|c|c|c|c|c|c|c|c|}
\hline \multirow[b]{2}{*}{$\begin{array}{l}\text { Country } \\
\text { (years) }\end{array}$} & \multicolumn{2}{|c|}{ Sales / workers } & \multicolumn{2}{|c|}{ VA / workers } & \multicolumn{2}{|c|}{ TFP } & \multirow{2}{*}{$\begin{array}{c}\text { Number of } \\
\text { observations } \\
\quad(N \times T)\end{array}$} \\
\hline & $\begin{array}{l}\text { Pooled } \beta \\
\text { ( } p \text {-value) }\end{array}$ & $\begin{array}{c}\text { Fixed } \\
\text { effects } \beta \\
\text { ( } p \text {-value) }\end{array}$ & $\begin{array}{l}\text { Pooled } \beta \\
\text { ( } p \text {-value) }\end{array}$ & $\begin{array}{c}\text { Fixed } \\
\text { effects } \beta \\
\text { ( } p \text {-value) }\end{array}$ & $\begin{array}{l}\text { Pooled } \beta \\
\text { ( } p \text {-value) }\end{array}$ & $\begin{array}{c}\text { Fixed } \\
\text { effects } \beta \\
\text { ( } p \text {-value) }\end{array}$ & \\
\hline $\begin{array}{l}\text { Belgium } \\
(1996-2005)\end{array}$ & $\begin{array}{c}60.8 \\
(0.00)\end{array}$ & $\begin{array}{c}9.9 \\
(0.00)\end{array}$ & $\begin{array}{c}9.0 \\
(0.00)\end{array}$ & $\begin{array}{c}1.4 \\
(0.04)\end{array}$ & $\begin{array}{c}0.7 \\
(0.36)\end{array}$ & $\begin{array}{c}3.6 \\
(0.06)\end{array}$ & 26,092 \\
\hline $\begin{array}{l}\text { China } \\
(1998-2005)\end{array}$ & $\begin{array}{l}11.7 \\
(0.00)\end{array}$ & $\begin{array}{c}8.8 \\
(0.00)\end{array}$ & $\begin{array}{c}1.3 \\
(0.00)\end{array}$ & $\begin{array}{c}6.6 \\
(0.00)\end{array}$ & $\begin{array}{l}-2.4 \\
(0.00)\end{array}$ & $\begin{array}{c}5.2 \\
(0.00)\end{array}$ & $1,138,350$ \\
\hline $\begin{array}{l}\text { Colombia } \\
(1981-1991)\end{array}$ & $\begin{array}{l}23.66 \\
(0.00)\end{array}$ & $\begin{array}{l}12.86 \\
(0.00)\end{array}$ & $\begin{array}{l}23.65 \\
(0.00)\end{array}$ & $\begin{array}{l}11.74 \\
(0.00)\end{array}$ & $\begin{array}{c}1.92 \\
(0.00)\end{array}$ & $\begin{array}{c}9.53 \\
(0.00)\end{array}$ & 44,425 \\
\hline $\begin{array}{l}\text { France } \\
(1990-2004)\end{array}$ & $\begin{array}{c}19.8 \\
(0.00)\end{array}$ & $\begin{array}{c}7.4 \\
(0.00)\end{array}$ & $\begin{array}{c}5.0 \\
(0.00)\end{array}$ & $\begin{array}{c}2.6 \\
(0.00)\end{array}$ & $\begin{array}{c}1.9 \\
(0.00)\end{array}$ & $\begin{array}{c}2.1 \\
(0.00)\end{array}$ & 293,196 \\
\hline $\begin{array}{l}\text { Rep. of Ireland } \\
(1991-2004)\end{array}$ & $\begin{array}{l}13.68 \\
(0.00)\end{array}$ & $\begin{array}{c}6.80 \\
(0.00)\end{array}$ & $\begin{array}{c}8.77 \\
(0.00)\end{array}$ & $\begin{array}{c}4.14 \\
(0.00)\end{array}$ & - & - & 26,472 \\
\hline $\begin{array}{l}\text { Italy } \\
(1989-1997)\end{array}$ & $\begin{array}{c}38.4 \\
(0.00)\end{array}$ & $\begin{array}{c}3.2 \\
(0.00)\end{array}$ & $\begin{array}{c}10.1 \\
(0.00)\end{array}$ & $\begin{array}{c}0.74 \\
(0.00)\end{array}$ & $\begin{array}{c}5.6 \\
(0.00)\end{array}$ & $\begin{array}{c}0.33 \\
(0.10)\end{array}$ & 169,778 \\
\hline $\begin{array}{l}\text { Slovenia } \\
(1994-2002)\end{array}$ & $\begin{array}{c}25.6 \\
(0.00)\end{array}$ & $\begin{array}{c}4.3 \\
(0.00)\end{array}$ & $\begin{array}{c}9.6 \\
(0.00)\end{array}$ & $\begin{array}{c}5.0 \\
(0.00)\end{array}$ & $\begin{array}{l}-1.5 \\
(0.32)\end{array}$ & $\begin{array}{c}2.9 \\
(0.22)\end{array}$ & 9,807 \\
\hline $\begin{array}{l}\text { United Kingdom } \\
(1995-2004)\end{array}$ & $\begin{array}{c}10.4 \\
(0.00)\end{array}$ & $\begin{array}{c}5.5 \\
(0.00)\end{array}$ & $\begin{array}{c}5.3 \\
(0.00)\end{array}$ & $\begin{array}{c}2.0 \\
(0.00)\end{array}$ & $\begin{array}{l}-0.6 \\
(0.37)\end{array}$ & $\begin{array}{c}0.4 \\
(0.68)\end{array}$ & 44,475 \\
\hline
\end{tabular}

Note: Results are for firms from ISIC industries 15-36 with at least 20 employees at the median over the years covered in the panel. The firms with the bottom/top 1 per cent of productivity in a year are excluded from all computations. $\beta$ is the estimated regression coefficient from an OLS-regression of $\log$ (productivity) on a dummy variable for exporting firms, controlling for the log of the number of employees and its squared value, the log of wages and salaries per employee, and a full set of interaction terms of 4-digit industry dummies and year dummies; the fixed effects model adds firm fixed effects. To facilitate interpretation the estimated coefficients for the exporter dummy variable has been transformed by $100(\exp (\beta)-1)$. $p$ is the prob-value. $N \times T$ is the number of observations.

coefficients become insignificant and some of the OLS estimates even turn negative. The preferred fixed effects results remain positive in each case and significantly different from zero at the 1 per cent level in three out of the seven cases. The magnitudes of the export premia are on average 40 per cent lower if TFP is used as the dependent variable rather than sales per worker.

We repeat the comparisons between export starters and non-starters three years before and three years after they enter the export market. Results are reported in ISGEP (2007). Concerning the selection hypothesis, the 
pattern is very similar to the results reported in Table 6. Most coefficient estimates remain positive using $V A / L$ as the dependent variable, but their size and significance are lower. The same is true for Belgium, China and Italy if we use TFP as the dependent variable, but for Colombia, France and the United Kingdom, negative effects dominate. These results suggest that firms invest in new capital equipment prior to entering the export market, mirroring the results for African firms in Van Biesebroeck (2005). In some cases, this explains the entire labour productivity effect. Concerning the learning-by-exporting question, results using $V A / L$ or $T F P$ as the dependent variables are very similar to those reported in Table 7 using sales per worker.

The second robustness check refers to the use of units with 10 or more employees. In order to ensure comparability across countries the main results had to be restricted to units-firms or establishments-with 20 or more employees. A full set of results is included in Appendix III of ISGEP (2007). Two main conclusions emerge from the evidence reported. First, the results for exporter productivity premia measured by export status indicate that exporters have significantly higher labour productivity than non-exporters. The size of the overall coefficient from the fixed effect regression is slightly larger for almost all countries when compared to the results for units with 20 or more employees. Second, where the ex ante exporter productivity premium was estimated to be positive and significant in the sample with 20 or more employees, this is confirmed by larger and more precise estimates for nearly all cases in the samples with 10 or more employees.

\section{Explaining Differences in Export Premia}

Our estimation of exporter premia across 14 countries in Table 4 using comparable methods allows us to address the following central question: what characteristics help explaining the differences in exporter premia across countries? Gravity models of international trade as well as recent theories of heterogeneous firms and trade (see Helpman (2006) and Greenaway and Kneller (2007) for review articles) guide to select a set of theoretically motivated variables that may be correlated with exporter premia across countries to include in the meta-regression analysis described below.

The main argument in the models of heterogeneous firms and trade is that fixed and variable costs of exporting ensure that only those firms with a productivity level above a critical threshold find it profitable to export 
in equilibrium (Melitz 2003). Consider for example fixed entry costs to export markets that differ across industries and trade costs that increase with distance introducing differences in variable costs of exporting across market destinations. This heterogeneity will reflect itself in different unobservable export productivity cut-offs (which determine the productivity level above which a firm decides to export) across active firms in the export market. The models predict that as the productivity cut-offs of exporting increase, certain firms no longer find it profitable to serve export markets. Thus, firm participation in export markets is negatively associated with the level of export productivity cut-offs.

Our exporter premia were estimated across countries with firm level information. Although these estimates incorporate a high degree of aggregation across different export destination markets and industries, they should still reflect the underlying factors (fixed costs of exporting and export productivity cut-offs) determining firm export participation. Therefore, we would expect that the higher is the critical level of productivity to enter the export market, the higher is the premium of exporting firms relative to firms that do not enter the export market. In what follows we will, therefore, treat the estimated exporter premia from each country as a proxy for the unobservable export productivity cut-off driving the decision of firms in that country to enter the export market.

The theoretical models of heterogeneous firms and trade suggest that one should expect a negative relationship between export participation and exporter premia across countries. The reason is that in countries where trade costs are lower more firms will be able to enter the export market, not just those at the very top of the productivity distribution.

Thus, one of the variables to include in our econometric analysis is export participation measured by the share of firms participating in export markets in each of the samples used to estimate the exporter premia. We also consider the average export intensity for firms participating in export markets in each of the samples used to estimate the exporter premia. The arguments motivating a potential relationship between export intensity and exporter premia were already introduced at the end of Section 3.

In these models, higher transport costs faced by exporters increase the cut-off productivity level required for exporting and thus the exporter premium. Unfortunately, we do not have direct measures of transport costs across countries but we argue that transport costs increase with distance to the markets served as is common in gravity models of bilateral trade. Thus, another variable to include in our econometric analysis is a measure of the 
distance to a country's exporting partners which is computed as an export value weighted average of the distances between each country and all its exporting partners.

The general trade policy environment of a country may also influence the size of the estimated exporter premia. In a country with a more restrictive trade policy stance, exporters tend to be discriminated against because they need to pay higher tariffs on the imported inputs that they generally use in production. This phenomenon of anti-export bias would suggest that firms which are able to break into export markets in such adverse environments would have to really stand out relative to the other firms and thus a very large exporter premium could be expected. The Melitz (2003) model shows that as a country liberalizes its trade policy, the productivity cut-off level for exporting declines and thus the expected exporter premium is lower, too. The rationale for this finding is that trade liberalization lowers export costs and thus makes exporting affordable for more firms with lower productivity. Hence, another variable to include in our econometric analysis is an average tariff measure to capture the trade policy stance in the country. ${ }^{17}$

We further include the GDP per capita of the exporter's home country. Based on firm level data for five East Asian countries, Hallward-Driemeier et al. (2002) find that the magnitude of the export premia is larger in countries with lower per capita income. Their interpretation for this finding is that underdeveloped countries have less-integrated markets, which allows non-exporters with low levels of productivity to survive. In contrast, in more developed economies domestic markets are more integrated, making it more difficult for low-productivity non-exporting firms to survive. The presence of a large number of low-productivity firms in countries with low per capita GDP implies that those that are able to afford the costs associated with exporting will be much more productive than the average firm.

Finally, the quality of a country's regulatory environment and government institutions may have a direct impact on the fixed and variable trade costs that firms located in that country face. Thus, heterogeneous models of firms and trade suggest that exporter premia should be lower in high quality environments because firms are likely to face lower costs of export-

\footnotetext{
17 The paper currently uses a measure of the average tariffs applied by the exporter's country instead of an average of the tariffs of the export destination markets. On the one hand, we chose this measure because we did not have tariff data for all destination countries and years to be able to construct the alternative measure. On the other hand, we think that our choice is defensible, as countries with high import tariffs increase exporters' costs.
} 
ing. Our econometric analysis considers the indices on the effectiveness of government and on regulatory quality calculated by Kaufmann et al. (2007) as proxies for the country's institutional environment.

Meta-analysis is a tool that can be fruitfully used to summarise, and explain variations in results of a number of similar empirical studies concerned with one research topic. ${ }^{18}$ Our meta-regression analysis consists of the estimation of an equation of the form:

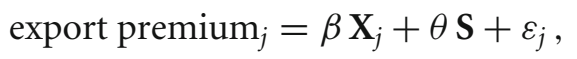

where the dependent variable are the exporter premia for each country $j$ summarized in Table 4 (the complete set of values used can be found in ISGEP (2007: Table 3)). The regressions pool 70 coefficient estimates corresponding to 14 countries times 5 size categories. ${ }^{19} X_{j}$ is one of the potential explanatory variables described above (see Appendix for the definition of these variables), and $\mathbf{S}$ is a vector of two size dummies indicating whether the exporter premium was estimated based on a sample of firms with less than 49 employees or whether the exporter premium was estimated based on a sample of firms with more than 50 employees. ${ }^{20}$ Note that in order to account for potential reverse causality, we include all of the explanatory variables at the beginning of the sample period for each country. In some of the specifications we allow $\mathbf{X}$ to be a vector that includes also variables relating to methodological characteristics. We allow the error term to be correlated within but not across countries.

The results for the meta-regression analysis are presented in Tables 9 and 10. Panels A and B of Table 9 provide the results based on the coefficients summarized in Table 4 that are estimated by firm fixed effects and by OLS, respectively (the variables used in the meta-analysis are described in detail in the appendix). We include one of the theoretically-motivated explanatory variables in each regression at a time because (i) those variables are highly correlated among each other; ${ }^{21}$ and, (ii) we have limited degrees of freedom in the meta-analysis regressions since our sample includes only

\footnotetext{
18 Görg and Strobl (2001) is a recent example of a meta-analysis in the international economics literature.

19 The size categories are 20-49 employees, 50-99 employees, 100-249 employees, 500 or more employees, and all sizes (ISGEP 2007).

20 The omitted category is the exporter premium estimated based on the full sample.

21 For example, the correlation coefficient between average distance to export partners and average tariff is 0.57 while the correlation between government effectiveness and average tariff is -0.81 , both significant at the 1 per cent level.
} 
Table 9: Determinants of Exporter Premia I

Panel A: Dependent Variable: Export Premia Estimated by Fixed Effects

\begin{tabular}{|c|c|c|c|c|c|c|c|}
\hline & (1) & (2) & (3) & (4) & (5) & (6) & (7) \\
\hline Average export participation & $\begin{array}{c}-0.099^{* * *} \\
(0.025)\end{array}$ & - & - & - & - & - & - \\
\hline Average export intensity & - & $\begin{array}{l}-0.060 \\
(0.049)\end{array}$ & - & - & - & - & - \\
\hline Average tariff & - & - & $\begin{array}{c}0.431^{* * *} \\
(0.111)\end{array}$ & - & - & - & - \\
\hline $\begin{array}{l}\text { Log of distance to exporting } \\
\text { partners }\end{array}$ & - & - & - & $\begin{array}{c}3.286^{* * *} \\
(0.875)\end{array}$ & - & - & - \\
\hline Log of per capita GDP & - & - & - & - & $\begin{array}{l}-2.111^{* * *} \\
(0.585)\end{array}$ & - & - \\
\hline Regulatory quality & - & - & - & - & - & $\begin{array}{c}-2.882^{* *} \\
(1.026)\end{array}$ & - \\
\hline Government effectiveness & - & - & - & - & - & - & $\begin{array}{c}-2.647^{*} \\
(1.263)\end{array}$ \\
\hline $\begin{array}{l}\text { Dummy for 20-49 employees } \\
\text { sample }\end{array}$ & $\begin{array}{c}-1.4135^{* *} \\
\quad(0.524)\end{array}$ & $\begin{array}{l}-0.363 \\
(0.501)\end{array}$ & $\begin{array}{l}-0.200 \\
(0.471)\end{array}$ & $\begin{array}{l}-0.200 \\
(0.471)\end{array}$ & $\begin{array}{l}-0.200 \\
(0.471)\end{array}$ & $\begin{array}{l}-0.200 \\
(0.471)\end{array}$ & $\begin{array}{l}-0.200 \\
(0.471)\end{array}$ \\
\hline $\begin{array}{l}\text { Dummy for } 50 \text { or more } \\
\text { employees samples }\end{array}$ & $\begin{array}{r}2.267^{* *} \\
(0.793)\end{array}$ & $\begin{array}{c}0.985 \\
(0.949)\end{array}$ & $\begin{array}{c}0.652 \\
(0.959)\end{array}$ & $\begin{array}{c}0.652 \\
(0.959)\end{array}$ & $\begin{array}{c}0.652 \\
(0.959)\end{array}$ & $\begin{array}{c}0.652 \\
(0.959)\end{array}$ & $\begin{array}{c}0.652 \\
(0.959)\end{array}$ \\
\hline Number of observations & 70 & 70 & 70 & 70 & 70 & 70 & 70 \\
\hline R-squared & 0.17 & 0.04 & 0.18 & 0.13 & 0.17 & 0.12 & 0.11 \\
\hline
\end{tabular}

Panel B: Dependent Variable: Export Premia Estimated by OLS

\begin{tabular}{|c|c|c|c|c|c|c|c|}
\hline & (1) & (2) & (3) & (4) & (5) & (6) & (7) \\
\hline Average export participation & $\begin{array}{c}0.034 \\
(0.123)\end{array}$ & - & - & - & - & - & - \\
\hline Average export intensity & - & $\begin{array}{l}-0.021 \\
(0.104)\end{array}$ & - & - & - & - & - \\
\hline Average tariff & - & - & $\begin{array}{l}-0.258 \\
(0.507)\end{array}$ & - & - & - & - \\
\hline $\begin{array}{l}\text { Log of distance to exporting } \\
\text { partners }\end{array}$ & - & - & - & $\begin{array}{l}-1.696 \\
(4.853)\end{array}$ & - & - & - \\
\hline Log of per capita GDP & - & - & - & - & $\begin{array}{c}0.834 \\
(1.942)\end{array}$ & - & - \\
\hline Regulatory quality & - & - & - & - & - & $\begin{array}{l}-0.133 \\
(2.978)\end{array}$ & - \\
\hline Government effectiveness & - & - & - & - & - & - & $\begin{array}{l}-0.201 \\
(4.128)\end{array}$ \\
\hline $\begin{array}{l}\text { Dummy for 20-49 employees } \\
\text { samples }\end{array}$ & $\begin{array}{c}1.875 \\
(1.555)\end{array}$ & $\begin{array}{c}1.406 \\
(1.026)\end{array}$ & $\begin{array}{c}1.464 \\
(0.964)\end{array}$ & $\begin{array}{c}1.464 \\
(0.964)\end{array}$ & $\begin{array}{c}1.464 \\
(0.964)\end{array}$ & $\begin{array}{l}1.4643 \\
(0.964)\end{array}$ & $\begin{array}{c}1.464 \\
(0.964)\end{array}$ \\
\hline $\begin{array}{l}\text { Dummy for } 50 \text { or more } \\
\text { employees samples }\end{array}$ & $\begin{array}{l}-4.032 \\
(3.108)\end{array}$ & $\begin{array}{l}-3.367 \\
(2.025)\end{array}$ & $\begin{array}{c}-3.486^{*} \\
(1.908)\end{array}$ & $\begin{array}{c}-3.486^{*} \\
(1.908)\end{array}$ & $\begin{array}{c}-3.486^{*} \\
(1.908)\end{array}$ & $\begin{array}{c}-3.486^{*} \\
(1.908)\end{array}$ & $\begin{array}{r}-3.486^{*} \\
(1.908)\end{array}$ \\
\hline $\begin{array}{l}\text { Number of observations } \\
\text { R-squared }\end{array}$ & $\begin{array}{c}70 \\
0.03\end{array}$ & $\begin{array}{c}70 \\
0.02\end{array}$ & $\begin{array}{c}70 \\
0.03\end{array}$ & $\begin{array}{c}70 \\
0.03\end{array}$ & $\begin{array}{c}70 \\
0.03\end{array}$ & $\begin{array}{c}70 \\
0.02\end{array}$ & $\begin{array}{c}70 \\
0.02\end{array}$ \\
\hline
\end{tabular}

Note: Standard errors clustered at the country level in parentheses. ${ }^{*},{ }^{* *}$ and ${ }^{* * *}$ indicate significance at the 10, 5 and 1 per cent confidence level respectively.

Source: Own calculations. 
Table 10: Determinants of Exporter Premia II

Panel A: Dependent Variable: Export Premia Estimated by Fixed Effects Adding Number of Observations in Export Premia Sample

\begin{tabular}{|c|c|c|c|c|c|c|c|}
\hline & (1) & (2) & (3) & $(4)$ & (5) & (6) & (7) \\
\hline Average export participation & $\begin{array}{l}-0.094^{* * *} \\
(0.030)\end{array}$ & - & - & - & - & - & - \\
\hline Average export intensity & - & $\begin{array}{l}-0.058 \\
(0.042)\end{array}$ & - & - & - & - & - \\
\hline Average tariff & - & - & $\begin{array}{c}0.409^{* * *} \\
(0.131)\end{array}$ & - & - & - & - \\
\hline $\begin{array}{l}\text { Log of distance to exporting } \\
\text { partners }\end{array}$ & - & - & - & $\begin{array}{c}3.045^{* * *} \\
(0.929)\end{array}$ & - & - & - \\
\hline Log of per capita GDP & - & - & - & - & $\begin{array}{c}-2.008^{* *} \\
(0.747)\end{array}$ & - & - \\
\hline Regulatory quality & - & - & - & - & - & $\begin{array}{c}-2.733^{*} \\
(1.356)\end{array}$ & - \\
\hline Government effectiveness & - & - & - & - & - & - & $\begin{array}{l}-2.404 \\
(1.471)\end{array}$ \\
\hline $\begin{array}{l}\text { Dummy for } 20-49 \text { employees } \\
\text { sample }\end{array}$ & $\begin{array}{c}-1.161^{*} \\
(0.578)\end{array}$ & $\begin{array}{c}0.196 \\
(0.634)\end{array}$ & $\begin{array}{c}0.141 \\
(0.568)\end{array}$ & $\begin{array}{c}0.070 \\
(0.435)\end{array}$ & $\begin{array}{l}-0.019 \\
(0.526)\end{array}$ & $\begin{array}{l}-0.086 \\
(0.532)\end{array}$ & $\begin{array}{c}0.051 \\
(0.511)\end{array}$ \\
\hline $\begin{array}{l}\text { Dummy for } 50 \text { or more } \\
\text { employees samples }\end{array}$ & $\begin{array}{r}2.667^{* *} \\
(0.985)\end{array}$ & $\begin{array}{l}2.362^{* *} \\
(1.052)\end{array}$ & $\begin{array}{c}1.503 \\
(1.223)\end{array}$ & $\begin{array}{c}1.327 \\
(1.225)\end{array}$ & $\begin{array}{c}1.105 \\
(1.413)\end{array}$ & $\begin{array}{c}0.936 \\
(1.420)\end{array}$ & $\begin{array}{c}1.279 \\
(1.216)\end{array}$ \\
\hline $\begin{array}{l}\text { Number of observations in } \\
\text { export premia sample }\end{array}$ & $\begin{array}{c}0.220 \\
(0.372)\end{array}$ & $\begin{array}{c}0.635 \\
(0.451)\end{array}$ & $\begin{array}{c}0.390 \\
(0.472)\end{array}$ & $\begin{array}{c}0.309 \\
(0.327)\end{array}$ & $\begin{array}{c}0.208 \\
(0.508)\end{array}$ & $\begin{array}{c}0.130 \\
(0.527)\end{array}$ & $\begin{array}{c}0.287 \\
(0.451)\end{array}$ \\
\hline Number of observations & 70 & 70 & 70 & 70 & 70 & 70 & 70 \\
\hline R-squared & 0.17 & 0.07 & 0.19 & 0.14 & 0.17 & 0.12 & 0.11 \\
\hline
\end{tabular}

Panel B: Dependent Variable: Export Premia Estimated by Fixed Effects Adding Dummy for Data Sets Based on Firms

\begin{tabular}{|c|c|c|c|c|c|c|c|}
\hline & (1) & (2) & (3) & $(4)$ & (5) & (6) & (7) \\
\hline Average export participation & $\begin{array}{c}-0.091^{* * *} \\
(0.026)\end{array}$ & - & - & - & - & - & - \\
\hline Average export intensity & - & $\begin{array}{l}-0.064 \\
(0.054)\end{array}$ & - & - & - & - & - \\
\hline Average tariff & - & - & $\begin{array}{c}0.409^{* * *} \\
(0.111)\end{array}$ & - & - & - & - \\
\hline $\begin{array}{l}\text { Log of distance to exporting } \\
\text { partners }\end{array}$ & - & - & - & $\begin{array}{l}2.984^{* *} \\
(1.044)\end{array}$ & - & - & - \\
\hline Log of per capita GDP & - & - & - & - & $\begin{array}{c}-1.938^{* * *} \\
(0.451)\end{array}$ & - & - \\
\hline Regulatory quality & - & - & - & - & - & $\begin{array}{l}-2.795^{* * *} \\
(0.812)\end{array}$ & - \\
\hline Government effectiveness & - & - & - & - & - & - & $\begin{array}{l}-2.299 \\
(1.335)\end{array}$ \\
\hline $\begin{array}{l}\text { Dummy for } 20-49 \text { employees } \\
\text { sample }\end{array}$ & $\begin{array}{c}-1.3157^{* *} \\
(0.521)\end{array}$ & $\begin{array}{l}-0.375 \\
(0.519)\end{array}$ & $\begin{array}{l}-0.200 \\
(0.474)\end{array}$ & $\begin{array}{l}-0.200 \\
(0.474)\end{array}$ & $\begin{array}{l}-0.200 \\
(0.474)\end{array}$ & $\begin{array}{l}-0.200 \\
(0.474)\end{array}$ & $\begin{array}{l}-0.200 \\
(0.474)\end{array}$ \\
\hline $\begin{array}{l}\text { Dummy for } 50 \text { or more } \\
\text { employees samples }\end{array}$ & $\begin{array}{c}2.1365^{* *} \\
(0.734)\end{array}$ & $\begin{array}{l}1.008 \\
(0.954)\end{array}$ & $\begin{array}{c}0.652 \\
(0.966)\end{array}$ & $\begin{array}{c}0.652 \\
(0.966)\end{array}$ & $\begin{array}{c}0.652 \\
(0.966)\end{array}$ & $\begin{array}{c}0.652 \\
(0.966)\end{array}$ & $\begin{array}{c}0.652 \\
(0.966)\end{array}$ \\
\hline
\end{tabular}


Table 10: Continued

Panel B: Dependent Variable: Export Premia Estimated by Fixed Effects Adding Dummy for Data Sets Based on Firms

\begin{tabular}{lccccccc}
\hline & $(1)$ & $(2)$ & $(3)$ & $(4)$ & $(5)$ & $(6)$ & $(7)$ \\
\hline Dummy for data sets based & -1.396 & -2.624 & -0.543 & -1.716 & -1.384 & -2.327 & -1.526 \\
$\quad$ on firms & $(1.365)$ & $(1.701)$ & $(1.825)$ & $(1.527)$ & $(1.621)$ & $(1.727)$ & $(1.915)$ \\
Number of observations & 70 & 70 & 70 & 70 & 70 & 70 & 70 \\
R-squared & 0.18 & 0.09 & 0.18 & 0.15 & 0.18 & 0.16 & 0.12 \\
\hline
\end{tabular}

Note: Standard errors clustered at the country level in parentheses. ${ }^{*}, * *$ and ${ }^{* * *}$ indicate significance at the 10, 5 and 1 per cent confidence level respectively.

Source: Own calculations.

14 countries. The results in Panel A show that average export participation is negatively and significantly correlated with the exporter premium. Average export intensity turns out to be not significant. Panel A shows that countries with more restrictive trade policies have significantly higher exporter premia. This result can be interpreted in light of the anti-export bias mentioned above: i.e. in such cases exporters need to be substantially more productive than non-exporters in order to expand into export markets. Panel A also shows that the higher is the average distance to the exporting partners the higher is the estimated exporter premium, as predicted by theory. Our results in Panel A furthermore show that the export premia is inversely related to per capita GDP, confirming the results from Hallward-Driemeier et al. (2002). Finally, countries with a more effective government and with better regulatory quality also exhibit lower exporter premia, as expected since firms in those countries are likely to face lower costs to enter export markets.

It is useful to show graphically some of the partial correlations between the exporter premia based on the coefficients summarized in Table 9 estimated by fixed effects and based on the full sample and some of the main variables of interest: tariffs, distance to the exporting partners and GDP per capita. The figures show clearly the positive correlations of the exporter premia with tariffs (Figure 1) and average distance to export destinations (Figure 2), and the negative correlation between the exporter premia with export participation (Figure 3) and with per capita GDP (Figure 4). However, it is clear that these correlations would not hold if we exclude Chile, China and Colombia from the figures, as the remaining EU countries are much more homogeneous in terms of their tariffs, distance to exporting partners and GDP per capita.

The results in Panel B of Table 9 show that none of the theoretically motivated variables are significantly correlated with the exporter premia. 
Figure 1: Exporter Premia and Tariffs

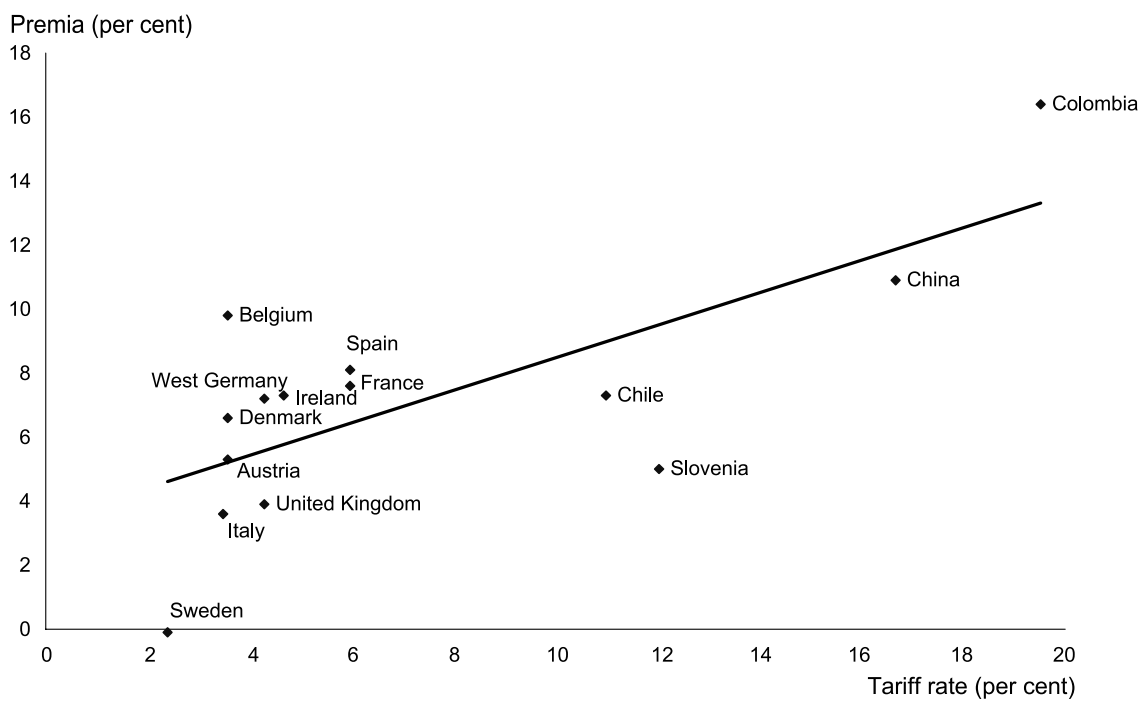

Figure 2: Exporter Premia and Distance

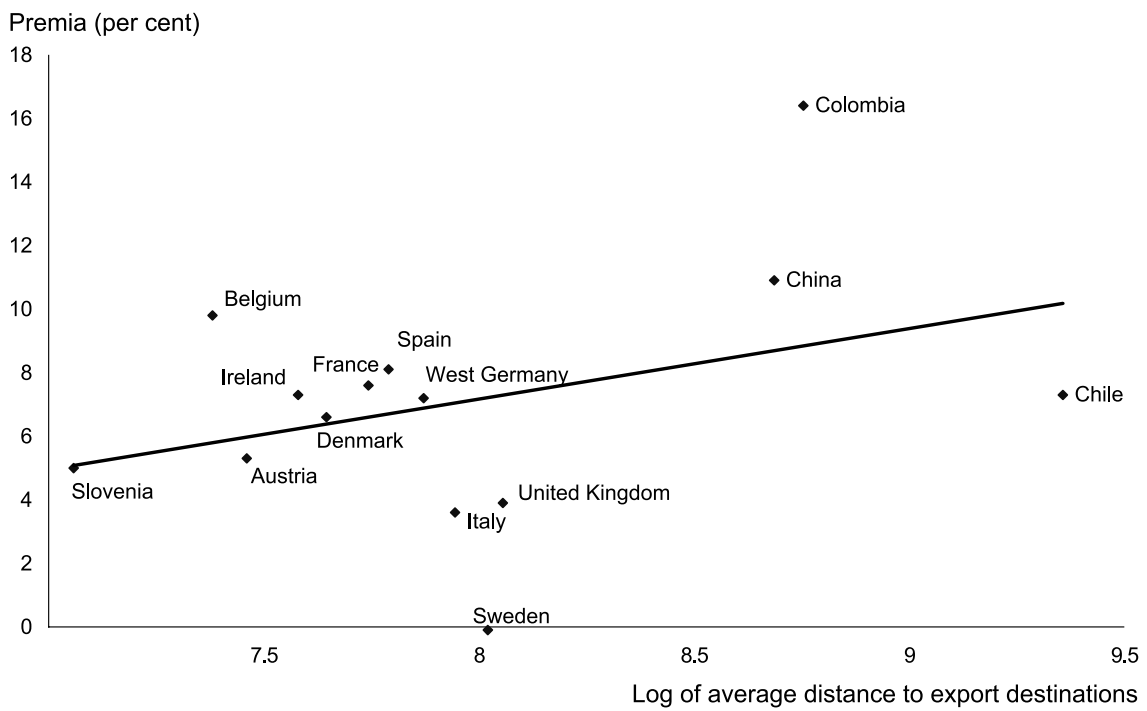

Moreover, for some of the variables, such as average export participation, the sign of the estimated coefficient is opposite of that found in Panel A and is against the theoretical predictions. A possible reason for this disparity could 
Figure 3: Exporter Premia and Export Participation

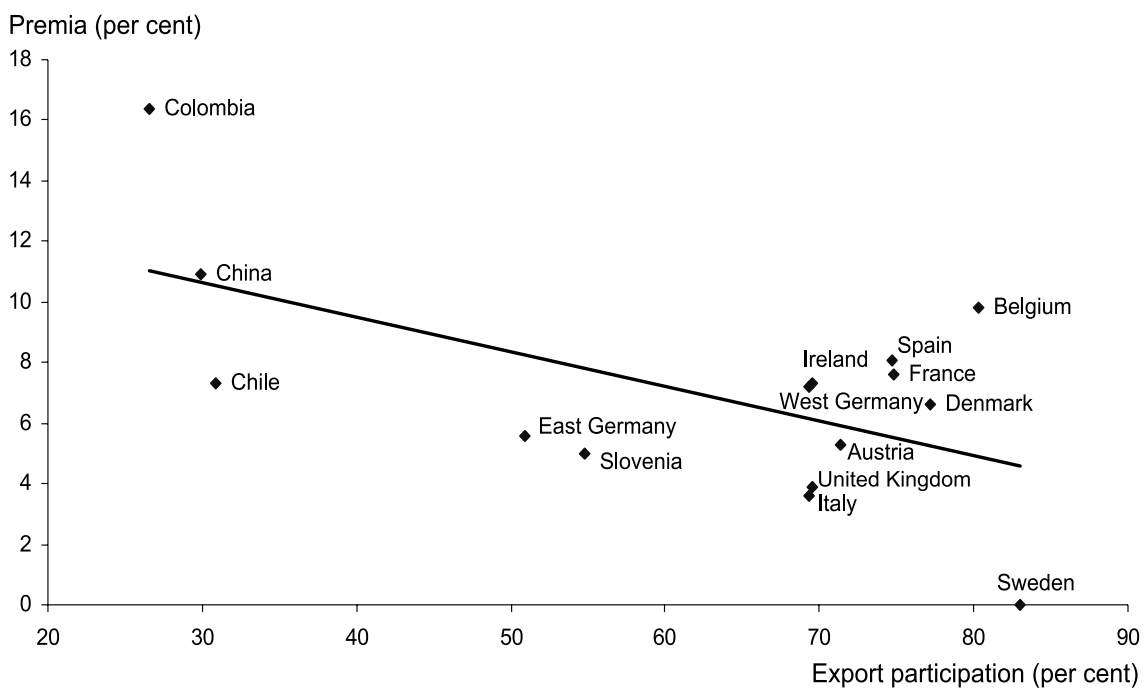

Figure 4: Exporter Premia and GDP Per Capita

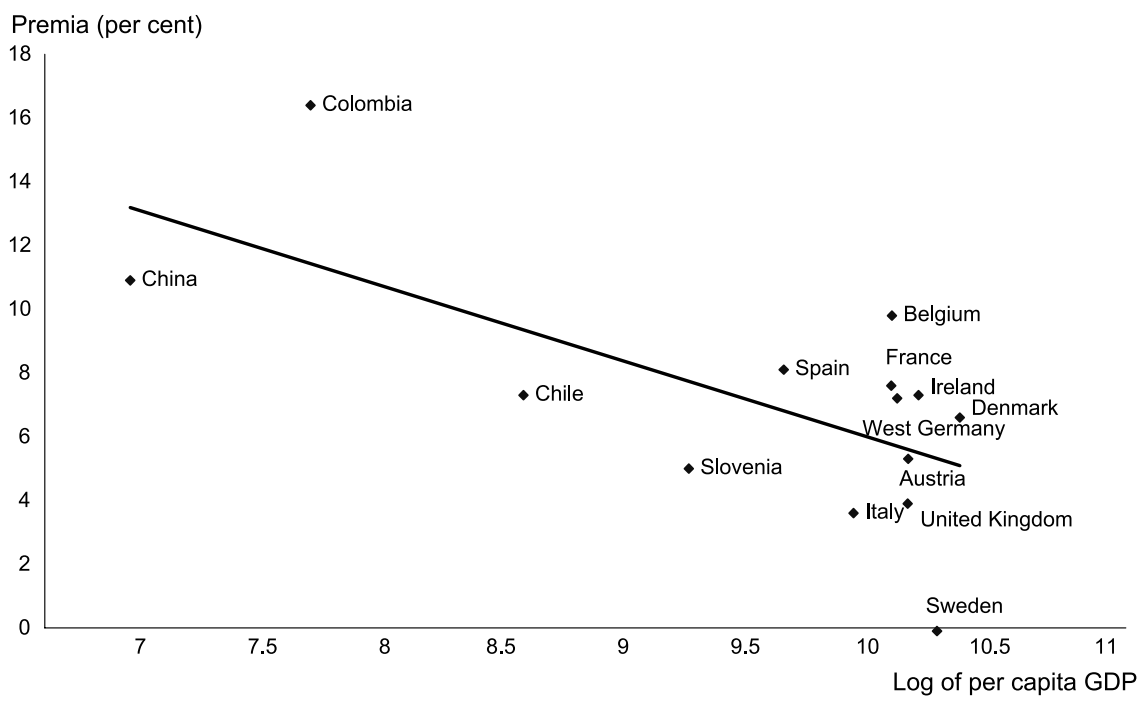

be that OLS estimates are biased in favour of capital-intensive countries. Recall that the dependent variable in the regressions to compute the exporter premium is labour productivity. In contrast, the fixed effects estimates 
control for capital and other factors of production such as managerial talent, which are roughly fixed at the firm level over the sample period. Thus, more capital-intensive firms appear as being more productive using OLS estimates, and as more capital-intensive firms are more likely to export, they will bias the estimated exporter premium upwards. Moreover, this bias is expected to be higher in EU countries because of the higher degree of capital intensity in their manufacturing industries, relative to developing countries. As a matter of fact, this is the case in our sample. The average bias for EU countries is 15 per cent, compared to 9 per cent for Chile, China and Colombia. The exporter premia estimated by OLS in developed countries causes the 'wrong' signs in our meta-regressions.

In Table 10, we use as dependent variables the coefficients estimated by firm fixed effects summarized in Table 4 (see ISGEP (2007: Table 3) for a complete presentation of the coefficients used in this estimation). In Panel A, we add to each specification the variable "number of observations included in the sample" for which the exporter premium was estimated. In Panel $\mathrm{B}$, we add to each specification a dummy identifying the countries whose data sets are based on firms rather than establishments. The important conclusion is that neither of these two variables return a statistically significant coefficient. This finding gives us some confidence that the potential differences in data sets across countries do not influence the estimated exporter premia. Moreover, the coefficients on the other explanatory variables are generally unchanged relative to those in Table 9.

\section{Concluding Remarks}

The overall results from our study that uses comparable micro level panel data for 14 countries to look at the relationships between exports and productivity using identically specified empirical models are in line with the big picture that is by now familiar from the literature: Exporters are more productive than non-exporters when observed and unobserved heterogeneity is controlled for, and these exporter productivity premia tend to increase with the share of exports in total sales. On the one hand, we find evidence in favour of the self-selection hypothesis for the less developed countries in our sample, and for all EU-countries with data sets including a large enough number of export starters to investigate this issue. On the other hand, we find evidence in favour of the learning-by-exporting hypothesis for one (Italy) out of 14 countries. 
These results are in line with those reported for many countries in the review article by Wagner (2007). However, the paucity of evidence on learning-by-exporting found in this paper should be qualified, as it might be dependent on the specific methodology utilized. For instance, a number of recent studies find a positive effect of export experience on productivity using more sophisticated estimation techniques and controlling for the bias caused by the self-selection of the most productive plants into exporting (Van Biesebroeck 2005; Isgut and Fernandes 2007; Lileeva and Trefler 2007; and De Loecker 2007). Moreover, the positive results for Italy are robust to the use of more sophisticated techniques such as propensity score matching and difference-in-differences (Serti and Tomasi 2008). More research is needed on this area.

Our results prove remarkably robust for value added per worker and TFP. The magnitudes of the exporter premia are lower if value added and TFP are used as measures of productivity rather than sales per worker. Independently of the measure of productivity used, the evidence obtained in favour of the self-selection and the learning-by-exporting hypotheses is very similar. Second, an additional robustness check that has been performed refers to the effect of including firms with 10 or more employees. Enlarging the sample of firms confirms the basic results obtained with the sample of units with 20 or more employees and, in general terms, produces larger and more precise estimates of current and ex ante exporter productivity premia.

The average exporter premium estimated for the 14 countries, after controlling for fixed effects, is 7 per cent. This premium varies substantially across countries. The large number of countries and the high degree of comparability of our results allow us to address a central question: what country characteristics help explain the differences in exporter premia across countries? We perform a meta-analysis to explain that cross-country variation in the productivity premia of exporters. Building on gravity models of international trade, as well as on recent theories of trade with heterogeneous firms, we explore the relationship between a set of country characteristics and the cross-country variation in exporters' premia. Consistent with theoretical predictions, we find that on average productivity premia are larger for countries with lower export participation rates, with more restrictive trade policies, lower per capita GDP, less effective government and worse regulatory quality, and for countries exporting to relatively more distant markets.

This paper focuses on the exports and productivity link. This narrow focus allows us to use more robust estimation methods and achieve greater 
international comparability. Exploiting the large number of countries and the high degree of comparability, we examine determinants of exporter premia suggested by recent theories of trade with heterogeneous firms. We are able to identify a systematic relationship between some country characteristics and the cross-country variation of exporter premia. A solid understanding of the nature and the causes of this relationship across countries is a pre-requisite for any sound policy-oriented arguments that might help to foster export-driven growth.

Finally, as in this paper we were interested in aggregated differences in the exporter premia across countries, we did not estimate our exporter premia separately by industry. However, we leave for future research the estimation of exporter premia from regressions conducted at the country and industry level.

\section{Appendix: Variables Used in Meta-Analysis Regressions}

The exogenous variables considered in the meta-analysis regressions-whose dependent variable is the export premia reported in Table 3 of ISGEP (2007)—are defined as follows:

1) Dummy for 20-49 employees sample: dummy variable indicating that the export premium is obtained for a sub-sample of firms in the size class 20-49 employees (ISGEP 2007: Table 3).

2) Dummy for other size samples: dummy variable indicating that the export premium is obtained for a sub-sample of firms in one of the following three size classes: 50-249 workers, or 250-499 workers, or more than 500 workers (ISGEP 2007: Table 3).

3) Average export participation: number of exporters over number of firms during the first year in the sample (ISGEP 2007: Table 2).

4) Average export intensity: average share of exports in firm sales for exporters during the first year in the sample (ISGEP 2007: Table 2).

5) Average tariff: effectively applied tariff rate in the initial year (or the first available year closer to that initial year) of each country's sample period (WITS database).

6) Log of distance to exporting partners: weighted average distance between exporter and export destination countries using the share of the value of exports to each country as weights (CEPII website and WITS database).

7) Log of per capita GDP: log of per capita GDP at purchasing power parity in constant 2000 international USD in the initial year of each country's sample period (World Development Indicators database).

8) Regulatory quality: normally distributed index with mean 0 and standard-deviation of 1 (across a total of 207 countries) whose higher values imply a better 
institutional framework. The index measures the ability of the government to formulate and implement sound policies and regulations that permit and promote private sector development (Governance Indicators of Kaufmann et al. 2007).

9) Government effectiveness: normally distributed index with mean 0 and standard-deviation of 1 (across a total of 207 countries) whose higher values imply a better institutional framework. The index measures the quality of public services, the quality of the civil service and its degree of independence from political pressures, the quality of policy formulation and implementation, and the credibility of the government's commitment to such policies (Governance Indicators of Kaufmann et al. 2007).

10) Number of observations in export premia sample: total number of observations used in the regression that estimated the export premium (ISGEP 2007: Table 3).

11) Dummy for data sets based on firms: dummy variable indicating that the export premium was estimated based on a sample whose unit of observation is a firm (ISGEP 2007: Table 1).

General note: the export premia for East Germany are excluded from the sample used for the meta-analysis regressions.

\section{References}

Andersson, M. (2007). Entry Costs and Adjustments on the Extensive Margin An Analysis of How Familiarity Breeds Exports. CESIS Working Paper. Royal Institute of Technology, Stockholm.

Andersson, M., S. Johansson, and H. Lööf (2008). Firm Performance and International Trade: Firm Level Evidence from a Small Open Economy. Review of World Economics/Weltwirtschaftliches Archiv 144 (4): 774-801.

Bartelsman, E. J., and M. Doms (2000). Understanding Productivity: Lessons from Longitudinal Data. Journal of Economic Literature XXXVIII (3): 569-594.

Bernard, A. B., and J. B. Jensen (1995). Exporters, Jobs, and Wages in U.S. Manufacturing: 1976-1987. Brookings Papers on Economic Activity: Microeconomics (1): 67-119.

Bernard, A. B., and J. B. Jensen (1999). Exceptional Exporter Performance: Cause, Effect, or Both? Journal of International Economics 47 (1): 1-25.

Bernard, A. B., and J. B. Jensen (2004a). Exporting and Productivity in the USA. Oxford Review of Economic Policy 20 (3): 343-357.

Bernard, A. B., and J. B. Jensen (2004b). Why Some Firms Export. The Review of Economics and Statistics 86 (2): 561-569.

Bernard, A. B., J. B. Jensen, S. J. Redding, and P. K. Schott (2007). Firms in International Trade. Journal of Economic Perspectives 21 (3): 105-130. 
Bernard, A. B., and J. Wagner (1997). Exports and Success in German Manufacturing. Weltwirtschaftliches Archiv/Review of World Economics 133 (1): 134-157.

Damijan, J. P., S. Polanec, and J. Prasnikar (2004). Self-Selection, Export Market Heterogeneity and Productivity Improvements: Firm Level Evidence from Slovenia. LICOS Discussion Paper 148. Katholieke Universiteit Leuven.

Damijan, J. P., and C. Kostevc (2006). Learning-by-Exporting: Continuous Productivity Improvements or Capacity Utilization Effects? Evidence from Slovenian Firms. Review of World Economics/Weltwirtschaftliches Archiv 142 (3): 599-614.

De Loecker, J. (2007). Do Exports Generate Higher Productivity? Evidence from Slovenia. Journal of International Economics 73 (1): 69-98.

Foster, L., J. Haltiwanger, and C. Syverson (2005). Reallocation, Firm Turnover, and Efficiency: Selection on Productivity or Profitability? IZA Discussion Paper 1705. Institute for the Study of Labour, Bonn.

Görg, H., and E. Strobl (2001). Multinational Companies and Productivity Spillovers: A Meta-Analysis. Economic Journal 111 (November): F723-F739.

Greenaway, D., and R. Kneller (2007). Firm Heterogeneity, Exporting and Foreign Direct Investment: A Survey. Economic Journal 117 (February): F134-F161.

Hallward-Driemeier, M., G. Iarossi, and K. L. Sokoloff (2002). Exports and Manufacturing Productivity in East Asia. A Comparative Analysis with FirmLevel Data. NBER Working Paper 8894. National Bureau of Economic Research, Cambridge, Mass.

Helpman, E. (2006). Trade, FDI, and the Organisation of Firms. Journal of Economic Literature XLIV (3): 589-630.

ISGEP (International Study Group on Exports and Productivity) (2007). Exports and Productivity - Comparable Evidence for 14 Countries. Working Paper Series in Economics 65. University of Lüneburg.

Isgut, A., and A. Fernandes (2007). Learning-by-Exporting Effects: Are They for Real? MPRA Paper 3121. University Library of Munich.

Kaufmann, D., A. Kraay, and M. Mastruzzi (2007). Governance Matters V: Governance Indicators for 1996-2006. World Bank Policy Research Working Paper 4280. The World Bank, Washington, D.C.

Lileeva A., and D. Trefler (2007). Improved Access to Foreign Markets Raises Plant-Level Productivity ... for Some Plants. NBER Working Paper 13297. National Bureau of Economic Research, Cambridge, Mass.

López, R. A. (2005). Trade and Growth: Reconciling the Macroeconomic and Microeconomic Evidence. Journal of Economic Surveys 19 (4): 623-648.

Máñez, J. A., M. E. Rochina-Barrachina, and J. A. Sanchis (2008). Sunk Costs Hysteresis in Spanish Manufacturing Exports. Review of World Economics/Weltwirtschaftliches Archiv 144 (2): 272-294.

Mayer, T., and G. I. P. Ottaviano (2007). The Happy Few: The Internationalisation of European Firms. Brussels: Bruegel. 
Melitz, M. J. (2003). The Impact of Trade on Intra-Industry Reallocations and Aggregate Industry Productivity. Econometrica 71 (6): 1695-1725.

Melitz, M. J., and G. I. P. Ottaviano (2008). Market Size, Trade, and Productivity. Review of Economic Studies 75 (1): 295-316.

Muûls, M., and M. Pisu (2007). Imports and Exports at the Level of the Firm: Evidence from Belgium. CEP Discussion Paper 801. Centre for Economic Performance, London.

Oulton, N., and M. O’Mahony (1994). Productivity Growth - A Study of British Industry 1954-1986. The National Institute of Economic and Social Research Occasional Papers XLVI. Cambridge: Cambridge University Press.

Rauch, J. E., and J. Watson (2003). Starting Small in an Unfamiliar Environment. International Journal of Industrial Organization 21 (7): 1021-1042.

Serti, F., and C. Tomasi (2008). Self-Selection and Post-Entry Effects of Exports: Evidence from Italian Manufacturing Firms. Review of World Economics/Weltwirtschaftliches Archiv 144 (4): 660-694.

Van Biesebroeck, J. (2005). Exporting Raises Productivity in Sub-Saharan African Manufacturing Firms. Journal of International Economics 67 (2): 373-391.

Van Biesebroeck, J. (2008). The Sensitivity of Productivity Estimates: Revisiting Three Important Productivity Debates. Journal of Business and Economic Statistics 26 (3): 311-328.

Wagner, J. (2007). Exports and Productivity: A Survey of the Evidence from FirmLevel Data. The World Economy 30 (1): 60-82. 